\title{
Studium nad intonacją wymowy scenicznej w spektaklach Jerzego Grotowskiego
}

\section{A Study of Scenic Speech Intonation in the Theatrical Adaptations by Jerzy Grotowski}

\author{
Adriana Gałdyńska-Mazan \\ Katedra Muzykologii, Uniwersytet im. Adama Mickiewicza \\ ul. Słowackiego 20, 60-823 Poznań \\ kmazan@poczta.fm
}

\begin{abstract}
In the present article, an attempt is made to analyse scenic speech intonation in the spectacles by Jerzy Grotowski. The intonational phenomena which are discussed here are interesting for both for linguistics and musicologists. They comprise a part of the phonosphere which includes also other kinds of sound phenomena such as non-articulated sounds, special (rhythmical) walking, jumping or employing theatrical requisites as musical instruments. The melo-rhythmical structure of intonation realized in the theatrical adaptations by Grotowski determines the character of segmental pronounciation, placing it between that typical of speaking and the one present in the singing voice.
\end{abstract}

Intonacja wymowy scenicznej w spektaklach Jerzego Grotowskiego jest ciekawym problemem badawczym nie tylko dla językoznawcy, ale i muzykologa. Jej budowa melodyczno-rytmiczna stanowiła o nieprzeciętnym wyrazie artystycznym inscenizacji realizowanych w latach 60-tych przez aktorów Teatru 13 Rzędów w Opolu, a następnie Teatru Laboratorium we Wrocławiu. Przyjęta przez zespół koncepcja „umuzycznienia” słowa zdecydowała o umiejscowieniu jego warstwy dźwiękowej na granicy mowy i śpiewu.

\section{Definicje intonacji}

Termin intonacja ma łacińską prowieniencję. Intono oznacza 'grzmię', 'rozbrzmiewam', 'wołam' (Tokarski 1980:313). W językoznawstwie intonację interpretuje się jako zespół zmian wysokości dźwięku w przebiegu wypowiedzi (Noteboom 1997:641) i analizuje się go pod kątem wzajemnych relacji zachodzących między wysokością dźwięku a semantyką, składnią i gramatyką (Ball i Rahilly 1999:113). Na podstawie współcześnie prowadzonych psychoakustycznych analiz intonacji mowy językoznawcy wysuwają pogląd, że intonację należy rozumieć jako zmiany percypowanej wysokości głosu w obrębie wypowiedzi. Wspomniane zjawisko powstaje nie tyle w samym sygnale mowy, co w umyśle słuchacza. W sygnale mowy zawarte są pewne wskazówki akustyczne, które w połączeniu ze specyfikacją ludzkiego układu percepcji dają określone wrażenia akustyczne ('t Hart, Collier, Cohen 1990:2-5). 
W muzykologii terminu intonacja używa się w odniesieniu do praktyki muzycznej, w której bada się dokładność wydobycia dźwięków głównie w śpiewie i w grze na instrumentach. Intonacją określa się także rozpoczęcie frazy muzycznej (Chodkowski 1995: 392-393; Oddham 2001:503).

\section{Twórcy teatralni wobec problematyki wymowy scenicznej}

Wymowa sceniczna i jej intonacja to zjawiska pod wieloma względami specyficzne ze względu na swoją sztuczność. Na proces wymowy składają się: fonacja, czyli wytwarzanie tonów lub szmerów, i artykulacja, to jest formowanie tych tonów lub szmerów w elementy mowy, czyli głoski. W wymowie scenicznej pewne sposoby artykulacji stosuje się celowo i świadomie, a odrzuca inne, które w odczuciu i rozumieniu artystów scenicznych zapewniają efekt mniej estetyczny lub narażają odbiorcę na to, że nie usłyszy on pełnego tekstu (Pawłowski 2005:319). Czynniki natury ekspresyjnej, które jak wiadomo odgrywają w teatrze istotną rolę decydują o dodatkowych elementach prozodii, jakimi są dynamika, barwa i przebieg czasowy dźwięku. Dyskusja nad prawidłami owej sztuki trwa w Polsce od początku wieku XX wieku. W ciagu całego minionego wieku wydano znaczną liczbę artykułów, broszur, podręczników na temat wymowy scenicznej (Nowakowski 1997:11). Zadawano w nich pytania, czym wymowa sceniczna jest, a czym nie jest, i jakim zasadom powinna być podporządkowana. W przyjętej przeze mnie koncepcji pracy wymową sceniczną nazywam rodzaj wymowy, który został zarejestrowany w sytuacji przedstawienia teatralnego.

Warto w tym miejscu nadmienić, iż zagadnienia wymowy scenicznej, a w tym poprawnej dykcji i znajomości ortofonii, interesowały niewielu teoretyków i ideologów teatru (Nowakowski 1997:67). Można co najwyżej wymienić Konstatina Stanisławskiego i Augustyna Tairowa rosyjskich reformatorów teatru, z których pierwszy odegrał kluczową rolę w kształtowaniu poglądów na istotę teatru i pracy aktora głoszonych przez Jerzego Grotowskiego. I tak w książce Stanisławskiego czytamy m. in.:

„Nareszcie zdałem sobie sprawę z tego, że każdy artysta musi posiadać doskonałą dykcję, wymowę, że musi wyczuwać nie tylko zdanie, wyraz, lecz również każdą zgłoskę. (...) Nie wymawianie poszczególnych zgłosek i głosek to tyle samo, co wybite oko lub ząb, oderżnięte ucho lub podobne potworności. Gdy niektórzy w skutek gnuśności i niechlujstwa czynią z wyrazów jakąś bezkształtną masę, przypominają mi się muchy, które ugrzęzły w miodzie, albo błoto i jesienne bezdroże, gdy wszystko zlewa się we mgle. Arytmia mowy, gdy wyraz lub zdanie zaczynamy powoli, w środku przyspieszamy tempo po to, żeby przy końcu jak gdyby prześlizgnąć się niespodzianie przez ciasny otwór, przypomina mi pijanego, a szybka mowa z połykaniem głosek - taniec św. Wita. (...)Niewyraźna wymowa stwarza jedno nieporozumienie za drugim. W miarę jak się nagromadzaja, cały sens, istota, a nawet fabuła sztuki staje się mglista lub zgoła niezrozumiała. Z początku widz wytęża słuch, uwagę, intelekt, żeby nie zgubić wątku; jeśli zaś to się nie udaje, zaczyna się denerwować, rozmawiać i wreszcie kaszlać. Czy zdajecie sobie sprawę z tego strasznego dla aktora słowa 'kaszlać'? Tysiączny tłum straciwszy cierpliwość i oderwawszy się od tego co się dzieje na scenie, może 'zakaszlać' aktorów, sztukę, przedstawienie.(...). Kaszlący widz - to najgroźniejszy nasz wróg. Jednym ze środków obrony przeciwko niemu jest piękna, wyraźna i plastyczna mowa " (1954:66).

A oto jeszcze jeden, krótszy cytat z tej samej książki odnoszący się do walorów dźwiękowych wymowy scenicznej:

„Każdy dźwięk składający się na wyraz posiada własną duszę, własną naturę, własną treść, które mówiący powinien odczuć. Jeżeli wyraz nie jest związany z życiem, lecz wygłoszony formalnie, mechanicznie, apatycznie, bezdusznie, przypomina trupa, w którym już ustało tętno.(...) Gdy zdałem sobie sprawę, że głoski są tylko symbolami dźwięków, które wymagają, aby napełnić je treścią, stała się oczywistością konieczność przestudiowania brzmienia tych dźwięków, żeby lepiej napełnić je treścią"(Stanisławski 1954:67).

Jerzy Grotowski deklarował nieco inny punkt widzenia niż Stanisławski. Polski twórca teatralny chętniej wypowiadał się na temat sposobu posługiwania się przez aktora otwartą krtanią, 
oddechem i "wibratorami" na potrzeby swobodnej wymowy. Krytykował on też praktykowane w szkołach teatralnych ćwiczenia blokujące krtań.

„W wielu szkołach teatralnych wykonuje się na przykład ćwiczenia na spółgłoski, ćwiczy się poprawną wymowę spółgłosek: 'p, d, t, s, c, b' i tak dalej, wymawia się też słowa, akcentując właśnie spółgłoski. W ten sposób także zamyka się krtań. Bo w rzeczywistości krtań może pozostawać otwarta, jeśli - przeciwnie - akcent pada na samogłoski. Jeśli pada on na spółgłoski, krtań się przymyka. Aby poprawnie artykułować, trzeba jakoś ćwiczyć się na spółgłoskach, zapewne; trzeba to jednak robić tak, aby samogłoski poprzedzały i następowały po spółgłosce 'a - ta', a nie 't,t,t'”' (Grotowski 1989b:114).

Aktorzy związani z Grotowskim, uświadomiwszy sobie braki w warsztacie aktorskim, rozpoczęli regularne ćwiczenia $\mathrm{w}$ zakresie ruchu i głosu oraz dykcji dopiero po inscenizacji Kordiana Słowackiego w trakcie przygotowań do Akropolis według Wyspiańskiego (Osiński 2000:111).

Wśród licznych wypowiedzi wspomnianego reżysera zachowały się też takie, które odnoszą się wprost do sposobu traktowania dźwięku mowy scenicznej. Potwierdzają one, że Grotowski wykazywał wysoką świadomość jakości dźwięku wymowy aktora i roli tego dźwięku w przekazywaniu widzowi określonego komunikatu w sytuacji spektaklu. Owa świadomość była efektem wieloletnich poszukiwań i badań reżysera oraz jego współpracowników w zakresie emisji głosu. Według przejętej od Stanisławskiego i rozwiniętej przez Grotowskiego idei działań fizycznych i wzbudzania w sobie impulsów wewnętrznych, mówienie lub reagowanie głosem odbywało się na zasadzie impulsu całego organizmu. Impuls miał charakter spontaniczny, a dźwięk był jego naturalnym "wierzchołkiem". Aparatura głosowa nie wymagała kontrolowanego ustawiania (Grotowski 1989a:38). "Impuls" należy w tym wypadku rozumieć jako wewnętrzną motywację, poprzedzającą reakcję fizyczną aktora (ruch bądź emisję głosu). Owa motywacja wyrasta z przywoływanego danym momencie przez aktora ważnego wspomnienia lub przeżycia doświadczonego w życiu wobec innego człowieka. Według Grotowskiego, istnienie będące celem impulsu, aktor rzutuje na drugiego aktora (partnera) jak na ekran - np. kobietę którą kiedyś spotkał - na aktorkę, z którą działa (Grotowski 1989c:117). Słowo rodzi się w tej sytuacji z reakcji ciała aktora, a z reakcji ciała rodzi się głos, a z głosu - mowa. „Jeżeli ciało staje się strumieniem żywych impulsów, nie stanowi żadnego problemu narzucenie nań pewnego układu zdań. (...) Impulsy pochłoną jak gdyby owe zdania, nie zmieniając ich - wchłona je. W takim wypadku interpretacja tekstu nie stanowi w ogóle problemu" (Grotowski 1972:114). To co dzieje się z aktorem, interpretuje tekst samo przez się.

W teatrze Grotowskiego wygłaszany przez aktora tekst traktowano jako bodziec (lub „trampolinę") do tworzenia przedstawienia autonomicznego względem oryginalnego tekstu dramatu. Grotowski stwierdził:

„nie interesuje mnie teatr słowa, bo oparty jest na fałszywym widzeniu istnienia ludzkiego. Nie interesuje mnie też teatr fizyczny. Bo co to w ogóle takiego? Akrobacje na scenie? Krzyk? Tarzanie się po podłodze? Przemoc? Ani teatr słowa, ani teatr fizyczny - ani teatr, ale istnienie żywe w swoim ujawnieniu. Stanisławski powiedział pewnego dnia: 'słowa są wierzchołkami działań fizycznych’. Bywa tak, że język mówiony jest tylko pretekstem”(1989c:161).

\footnotetext{
1 Jednym $\mathrm{z}$ aspektów pracy aktorów laboratorium teatralnego kierowanego przez Grotowskiego było ćwiczenie rezonatorów ciała w celu uzyskania dźwięku o określonej barwie i mocy. Grotowski, formułując tezę o efektywnym wykorzystaniu organizmu aktora dla wzmocnienia dźwięku, zastrzegł, że terminu "rezonator" używa w sensie konwencjonalnym oraz że nie zostało naukowo stwierdzone, jakoby określone cześci ciała (w wyjątkiem usytuowanych ponad krtanią) stanowiłyby obiektywne instrumenty wzmacniające dźwięk. Grotowski umiejscawiał tę tezę na granicy autosugestii i prawdy obiektywnej. Miał on świdomość istnienia obowiązującej w nauce koncepcji, iż funkcję rezonacyjną pełnią przestrzenie nadkrtaniowe (jama gardłowa, okolice twarzowo-czaszkowe). Chcąc wyrazić się bardziej precyzyjnie, Grotowski w swoim tekście pt. Głos (Grotowski 1989b), zastosował już termin "wibrator" zamiast "rezonator", podkreślając fakt, iż z naukowego punktu widzenia rezonans w ciele powstaje tam, gdzie są kości. Pozostałe narządy natomiast (klatka piesiowa, kręgosłup, barki, jama brzuszna), w trakcie wydobywania przez aktora głosu, podlegają "rozwibrowaniu", wobec czego trafniejszym określeniem charakteryzującym ich funkcję wydał się Grotowskiemu termin "wibratory". Termin "wibratory" Grotowski odnosił do wszystkich narządów mających jakikolwiek wpływ na jakość dźwięku (w tym również do okolic gardła i twarzo-czaszki).
} 
Domeną twórczości w teatrze Grotowskiego miał być „montaż tekstu, montaż słów z zachowaniem się osób grających, formowanie w ruchu impulsów i reakcji fizycznych, formowanie z materiału słów mowy żywej, wraz z jej akustyką" (Grotowski 1989a:39). Owa akustyka stanowiła - obok muzyki - istotny element fonosfery każdego spektaklu. Grotowski pojmował muzykę w sposób szerszy niż czynią to ludzie bezpośrednio związani z tą dziedziną sztuki. Jego zdaniem cała sfera dźwiękowa przedstawienia, a więc nie tylko kompozycja głosów aktorów, ale i efekty uderzenia przedmiotem o przedmiot (np. butem o podłogę) stanowiła o muzyczności widowiska. W mniemaniu Grotowskiego tekst sam w sobie nie należy do domeny teatru. Tekst ten wchodzi w jej obręb dopiero poprzez to, co z nim uczyni aktor, tzn. jako intonacja, jako skojarzenia dźwiękowe, jako język umuzyczniony (Grotowski 1989:15).

\section{Specyfika wymowy scenicznej i jej intonacji według historycznych źródel bezpośrednich i pośrednich}

Dostępne nagrania spektakli teatralnych Kaina, Tragicznych Dziejów Doktora Fausta, Akropolis, Księcia Niezłomnego i Apocalypsis cum figuris reprezentują bardzo słabą jakość, mimo to jednak $\mathrm{w}$ dużej mierze pozwalają na przeprowadzenie analizy instrumentalnej i odsłuchowej w zakresie prozodii. Studium wymowy scenicznej realizowanej w pozostałych przedsięwzięciach teatralnych jest możliwe na podstawie programów do spektakli pisanych przez Ludwika Flaszena (kierownika literackiego Teatru 13 Rzędów i Teatru Laboratorium) i recenzji prasowych sporządzanych przez krytyków. Materiał ten nie jest wprawdzie zbyt obszerny, ale cenny dla przeprowadzenia pełniejszej charakterystyki wymowy scenicznej i jej intonacji obecnej w spektaklach prezentowanych przez wspomniany zespół.

Słowo traktowano w przedstawieniach Grotowskiego z rodzajem pietyzmu przejawiającego się w inkantacji i budowie melodycznej frazy (Osiński i Burzyński 1979:13). Należy jednak podkreślić, że Teatr 13 Rzędów (jako typ teatru eksperymentalnego) proponował widzowi dialog nie ograniczający się jedynie do słowa. Był to dialog, w którym na równi z tekstem - mówiły inne elementy przedstawienia: plastyka, ruch, światło, dźwięk itp. Nie służyły one wydobywaniu i punktowaniu treści, które niesie tekst - lecz wspólnie z nim budowały nadrzędną treść przedstawienia. $\mathrm{W}$ tak pojmowanym dialogu słowo było tylko jednym $\mathrm{z}$ partnerów (Flaszen 1983:274-275).

Postawa nowatorskiego podejścia do wymowy i intonacji tekstu została zrealizowana już pierwszym spektaklu pt. Orfeusz Jeana Cocteau. W recenzji tego widowiska czytamy m. in.

„Poetyckie tyrady (bardzo zresztą piękne), które na scenie opolskiej poddaje się najwymyślniejszym torturom, nie ujawniają ani intelektualnego dowcipu koniecznego w imprezie tego typu, ani celnej lapidarności. Śpiewane, recytowane na zasadzie kulomiotu, ośmieszane błazenadą grymasów i wygłupów - nie stają się niczym innym niż pokaleczoną wielką poezja, sprowadzoną do roli niezręcznego i żałosnego klowna” (Eberhardt 1960:7).

W następnym spektaklu pt. Kain Byrona wiersz także potraktowano zmiennie, zależnie od stosunku inscenizacji do tekstu. Według Flaszena określone fragmenty wypowiadano z uwzględnieniem jego subtelności intonacyjnych, albo na zasadzie parodystycznego „bębnienia”, inne jeszcze na zasadzie arii operowych lub z całkowitym zatarciem rytmu, jakby sprowadzając tekst do prozy, do mowy codziennej (Flaszen 1983:268). Agnieszka Wójtowicz współcześnie stawia śmiałą tezę, iż Grotowski świadomie odrzucił sposób podania tekstu, który uwzględniałby styl wiersza byronowskiego, przepełnionego patosem. Jego młody i niedoświadczony wówczas zespół aktorski mógł jej zdaniem nie poradzić sobie z tym wyzwaniem. Reżyser ukrywał aktorskie niedostatki wprowadzając serię pomysłów, takich jak ustawiczne zmiany tempa i sposobów podania słowa, polegających na parodystycznym, afektowanym mówieniu, bełkotliwej galopadzie lub stylizacji na wzór arii operowych (Wójtowicz 2004:33-34). Teza Wójtowicz nie znajduje potwierdzenia w wypowiedziach Grotowskiego. Koncepcja reżysera dotycząca zróżnicowania intonacji wynikała z przyjętej przez niego strategii myślenia o teatrze. Tu przypomnę raz jeszcze deklarację reżysera: „nie interesuje mnie teatr słowa”.

Kain był drugim i jednocześnie ostatnim po Orfeuszu spektaklem, w którym wykorzystano też muzykę mechaniczną. W obu spektaklach zaangażowano konsultanta muzycznego, którym był kompozytor Jerzy Kaszycki. Znacznie bardziej płodne okazały się jednak doświadczenia zdobyte 
w trakcie przygotowywania spektaklu pt. Siakuntala według Kalidasy, będącego trawestacją staroindyjskiej baśni dramatycznej. Inscenizator przywiązywał dużą wagę do tzw. ,aktoro-muzyki” i „aktoro-plastyki”, wykorzystując naturalne efekty dźwiękowe (rytmiczne uderzenia, odgłosy kroków) i organizując swoistą , architekturę form, barw, dźwięków, języków i śpiewów” (Osiński i Burzyński 1978:19). To w jaki sposób aktorzy traktowali słowo i jego intonację w tym przedstawieniu ukazują następujące relacje:

„Słowo sceniczne potraktowane zostało bardzo umownie. Ma ono być nie tylko nosicielem znaczeń i intencji, przekaźnikiem treści, lecz winno również układać się w plamy dźwiękowe, grać sztucznością" (Flaszen 1983:292).

Recenzentka „Sztandaru Młodych” pisała o tym przedstawieniu jak następuje: „Sposób podawania słowa odwołuje się do indyjskich mantramów (zaklęć). Słowo to nie tylko pojęcie, które z nim wiążemy, nawet nie przede wszystkim pojęcie, słowo to dźwięk" (Leja 1961:2).

Tadeusz Kudliński na łamach „Dziennika Polskiego” odnotował: „(...)przesadą wydają się karkołomne, akrobatyczne wyczyny aktorów, utrudniające tylko wygłoszenie. W ogóle styl ten stawia niezwykłe wymagania aktorom, wymagania niebywałej u aktorów sprawności fizycznej, także głosowej, przy nieustannych zmianach intonacji, barwy i nasilenia głosu (od krzyku do szeptu), którym towarzyszy nieustanny ruch (także aktorów chwilowo nie zajętych)" (1961: 4).

Z kolei w „Argumentach” Jerzy Lau napisał:

„Małą scenkę en ronde (Grotowski) wypełnia rzeczywiście scenicznym ruchem, ciekawą architekturą form, barw, dźwięków, języków i śpiewów”(1961: 8). Inny recenzent - Olgierd Jędrzejczyk na łamach gazety Krakowskiej - podkreślał zasługi dwojga aktorów (Reny Mireckiej i Zygmunta Molika), którzy jego zdaniem umieli ,doskonale z systemu nieoczekiwanych zawieszeń glosu i pokrzykiwań - przeskoczyć po prostu w atmosferę prawdziwej poezji, recytowanej z dużym mistrzostwem"(Jędrzejczyk 1960:8). Zbigniew Osiński wraz z Tadeuszem Burzyńskim podsumowali spektakl jak następuje: „Znamienną cechę stanowiły sztucznie komponowane sposoby mówienia aktorów. Odwoływano się przy tym do konwencjonalnych brzmień sakralnych i aluzji liturgicznych, co często pozostawało w sprzeczności w potocznym znaczeniem słowa; ta antynomia była świadomie wygrywana".

Różnorodność intonacji w Siakuntali została wykorzystana także w kolejnej inscenizacji Grotowskiego - w Dziadach Mickiewicza. W komentarzu do przedstawienia autorstwa Ludwika Flaszena, odnośnie interesującej nas kwestii, czytamy: „W mówieniu pietystycznie przestrzega się wszelkich osobliwości mickiewiczowskiego języka - niechaj tradycji stanie się zadość" (Degler, Ziółkowski 2006:42). Owe osobliwości podkreślano niekiedy prowokacyjnie (Flaszen 1983:312). Zdaniem jednego z obserwatorów tego widowiska „tym sposobem natrętna 'wierność' wobec autorskiego przekazu obracała się w swego rodzaju 'efekt obcości', wykładnik ironicznego dystansu" (Majchrowski 1998:110). Z kolei w innej relacji o przedstawieniu cytowanego już wcześniej Ludwika Flaszena czytamy m. in.

„Gustaw - (w akcie II) - rozgrywa swój dramat ostentacyjnie, jakby na pokaz. Kiedy rozczula się nad sobą lirycznie, głos ucieka mu w górne rejestry belcanta, a ciało układa się w pozy afektowane, omdlewające. Kiedy popada w gwałtowną rozpacz i obłąkanie, pohukuje basem, czyni groźne miny, przybiera pozy nagłe, dziwaczne, obliczone na komedianckie zastraszenie partnerów i widzów. Gdy sprzeciwia się chrześcijańskiemu konformizmowi księdza, posuwa się aż do bluźnierstwa: jest $\mathrm{w}$ tym coś $\mathrm{z}$ donżuanowskich wybryków metafizycznych, $\mathrm{z}$ ponurego humoru świętokradcy nastawionego na doraźny efekt. Recytuje wiersze melodyjnie, ustawicznie ciążąc ku śpiewowi: wręcz śpiewa w kulminacyjnych fragmentach roli. Patetyczny w wyrazie, podszyty jest dzieckiem. I pokrewny księżym dzieciom - śmieszny, lecz politowania godny” (Flaszen 1983:314). W akcie III natomiast „monolog Konrada ujęto w formę drogi krzyżowej. Słowa rewolty głosi pokornie uginając się pod krzyżem, który na domiar nie jest wzniosłym narzędziem męki, lecz zwykłą domową miotłą. Krąży po całej sali, padając od czasu do czasu pod ciężarem swego trywialnego rekwizytu w ikonograficznych pozach Chrystusa w drodze na Golgotę. Chrystus chwilami nieludzko cierpiący, zdziecinniały, chwilami zaś bezradnym dyszkancikiem wymyślający własnemu 
okrutnemu Ojcu. Z zewnątrz dolatują melodie godzinek - pobożne głosy kobiece nucą bluźniercze fragmenty Wielkiej Improwizacji” (Flaszen 1983:316). Według relacji Konstantego Puzyny (odnośnie omawianej inscenizacji) aktorzy zacierali warstwę słowną ,zazwyczaj na rzecz ekspresji wokalnej oraz sytuacji foniczno-ruchowej, uzyskując tu zresztą efekty olśniewające. Grotowski akcentował co prawda także stronę emocjonalną, rytmiczną i magiczną słowa, lekceważył jednak warstwę znakową, a z nią i poezję słów, literaturę" (Majchrowski 1998:114).

Inscenizację Kordiana skomentował m. in. Tadeusz Kudliński na łamach Dziennika Polskiego: „(...) jest to zespół o zdumiewającej sprawności i kondycji. Opanowanie pamięciowe, przy frenezji mówienia i niezwykle trudnych układach sytuacyjnych, skala głosu od krzyku i śpiewu do szeptu, nieustanna zmiana barwy i intonacji, pewność i swoboda w atakowaniu kwestii i ryzykownych sytuacji, wreszcie skupienie - to są wymogi, a zarazem osiagnięcia niezwykłe na naszych scenach" (Wójtowicz 2004:83).

Ekspresję mowy aktorskiej rozszerzono znacznie dopiero w Akropolis. Jak pisał Falszen - w zakresie komponowania wymowy scenicznej i jej intonacji skorzystano w różnorakich form. „Od bełkotu i mamrotania, jakby cofając się w fazę dziecinną lub pierwotną języka, gdy stanowił spontaniczne sygnały uczuć - do melodyjnej, wyszukanej recytacji; od nieartykułowanych krzyków, pomruków i mlaskotów, pokrewnych odgłosom zwierzęcym do tkliwej ludowej kantyleny i liturgicznych śpiewów; od kalikujących gwar i 'żydłaczenia' w scenach biblijnych - do górnego frazowania świętych ksiąg i poetów. W tej złożonej partyturze dźwięków przywołano wspomnienie różnych form i zastosowań języka. Pomieszano i skłócono - niby w nowej wieży Babel - w rozgwarze różnych ludów i czasów, na moment przed zagładą" (Flaszen 1983:334-335).

A oto relacja autorstwa Leonii Jabłonkówny z kolejnej inscenizacji pt. Ksiażę Niezłomny „(...) wprawdzie dochodzą do nas ze sceny pojedyncze słowa i całe frazy, w których rozpoznajemy tekst dobrze nam znany, tekst Słowackiego; ale te słowa w ustach wykonawców przybierają zupełnie nieoczekiwane akcenty i egzotyczną modulację, chwilami zatracają się w powodzi towarzyszących im dźwięków - chrapliwych okrzyków, zdławionych szeptów, osobliwych zawodzeń i pogwizdywań; w połączeniu z całym zespołem działań fizycznych, o zupełnie odmiennym, często wręcz sprzecznym z ich pierwotną treścią charakterze, słowa te odrywają się od swego naturalnego podłoża, traca swą dawną funkcję znaczeniowa, przekształcają się w jakiś tajemny szyfr, do którego nie mamy klucza”(Degler, Ziółkowski 2006:179).

O wymowie scenicznej realizowanej przez aktorów w ostatnim spektaklu wyreżyserowanym przez Grotowskiego, pt. Apocalypsis cum figuris, wypowiedział się (poprzez metaforę) Tadeusz Różewicz:

„Oni rodzą te teksty, rodzą raz jeszcze. Rodzą je w każdym nowym przedstawieniu. Ryki rodzącego rozlegają się $\mathrm{w}$ tej zamkniętej sali teatralnej (a raczej operacyjnej). Słowo na naszych oczach staje się ciałem, rośnie w czasie przedstawienia. Zamienia się w ciało agresywne. Gwałcone i gwałcące. Ten zespół karmi się słowem (dosłownie). Słowo jest tu trawione i wydalane. Słowo jest tu wykrwawione, rozdzierane, zbite na miazge, odrzucone. $\mathrm{Z}$ jego boku tryska strumień krwi, spermy, milczenia. Tu odbywa się karmienie słowem. Godzina karmienia: dziewiętnasta. Pomruki, mlaskanie, milczenie. Ryki. W skurczach i rozkurczach tego organizmu słowo jest wydalane. Słowo w tym przedstawieniu zostaje unieważnione. Dać Grotowskiemu tekst - to dać istotę żywą na pożarcie. To nie jest ani współpraca, ani obcowanie, to jest pewien rodzaj ofiary” (Degler, Ziółkowski 1996:206).

Tyle informacji na temat interesującej nas problematyki można pozyskać ze źródeł bezpośrednich (wypowiedzi Flaszena) i pośrednich (widzów - krytyków teatralnych). Istnieją jeszcze relacje odnoszące się do kwestii stricte muzycznych, ale te nie są przedmiotem niniejszego referatu. 


\section{Językoznawcza koncepcja intonacji języka polskiego ogólnego}

Studium intonacji wymowy scenicznej na podstawie nagrań spektakli wyreżyserowanych przez Jerzego Grotowskiego winno zostać poprzedzone kilkoma uwagami odnoszącymi się do współczesnej, językoznawczej koncepcji intonacji języka polskiego ogólnego. Intonacja spełnia w języku polskim m.in. funkcję ekspresywną, a zatem stanowi wykładnik stosunku mówiącego do sytuacji, w jakiej się on znajduje, do przedmiotu rozmowy i do osoby, pod której adresem wypowiedź została skierowana (Steffen-Batogowa 1996:163). Językoznawcy do niedawna spierali się co do tego, czy zdania, jako pewne formy gramatyczne lub też jako komunikaty określonych stanów emocjonalnych i intencji można kategoryzować. Niektórzy bowiem twierdzili, że zbiór wszystkich zdań języka polskiego można poklasyfikować na takie typy zdaniowe, iż klasy przebiegów intonacyjnych występujących w połączeniu ze zdaniami poszczególnych typów będą między sobą całkowicie rozłączne. Innymi słowy, że możliwe jest jednoznaczne stwierdzenie, że np. zdania pytające charakteryzują się przebiegiem intonacyjnym wznoszącym, zdania oznajmujące - rosnąco-opadającym, a rozkazujące - opadającym. Badania przeprowadzone $\mathrm{w}$ ostatnich latach wykazały jednak, iż żadna $\mathrm{z}$ prób wyodrębnienia określonych kategorii zdaniowych ze względu na im tylko właściwe przebiegi intonacyjne nie powiodła się. Intonacja jest po prostu wypadkową wielu czynników, takich jak kategoria gramatyczna zdania, kontekst sytuacyjny i zabarwienie emocjonalne wypowiedzi (Steffen-Batogowa 1996:162). W świetle obserwacji dokonywanych na korpusach mowy spontanicznej wysuwa się tezę, że istnieją wypowiedzi stanowiące twór pośredni, między pytaniem a stwierdzeniem. Występowanie np. rosnących melodii rdzennych obserwuje się bowiem nie tylko $w$ pytaniach, ale też w stwierdzeniach lub poleceniach (Karpiński 2006:59). Na podstawie analiz językoznawczych dotyczących specyfiki języka polskiego stwierdzono także, iż kontury intonacji opadającorosnących i rosnąco-opadających są charakterystyczne przede wszystkim dla wypowiedzi ekspresywynych oraz o ponadprzeciętnym ładunku emocjonalnym (Karpiński 2006:190). Dla porównania $\mathrm{w}$ zakresie intonacji wypowiedzi poprawnie zbudowanych i neutralnych emocjonalnie odnotowuje się sporadyczne istnienie konturów melodii rdzennej rosnąco-opadającej. Mowa spontaniczna dalece różni się od mowy scenicznej będącej sztucznym wytworem i jednocześnie pewną odmianą mowy starannej. Można założyć, iż intonację mowy starannej będzie głównie determinował czynnik odnoszący się do struktury syntaktycznej i kategorii zdaniowych, a więc decydujący o wyróżnieniu komponentów zdania złożonego bądź odróżnienia pytania od stwierdzenia (Karpiński 2006:59). W przypadku jednak wymowy scenicznej realizowanej przez aktorów Teatru 13 Rzędów, a następnie Teatru Laboratorium, decydującą rolę w kształtowaniu intonacji odgrywała a priori przyjęta koncepcja celowego umuzycznienia słowa wraz z czynnikiem emocjonalnym. Na koniec warto jeszcze dodać, iż językoznawcy skłonni są traktować czynnik afektywny jako pozajęzykowy składnik intonacji, który wymaga rozdzielenia w procesie analizy od składnika językowego (gramatycznego) (Gussenhoven 2004). Coraz więcej pojawia się jednak głosów, które podkreślają konieczność całościowego traktowania intonacji pojmowanej w kategorii pewnej całości. Czynnik afektywny uważa się za integralny element pierwotnej, przedwerbalnej formy komunikatu. Barwa głosu i intonacja ulegają zmianom, które wynikaja ze zjawisk fizjologicznych, towarzyszącym emocjom, takich jak np. podwyższone napięcie mięśniowe lub drżenie mięśni. W mowie silnie emocjonalnej wpływom afektywnym podlegają zarówno rama syntaktyczna, jak i procesy tworzenia komend motorycznych lub sama artykulacja (Karpiński 2006:191).

\section{Metody analizy}

W analizie intonacji wymowy scenicznej w laboratorium teatralnym Jerzego Grotowskiego posłużyłam się metodą instrumentalną i odsłuchową. Metoda instrumentalna polega na poddaniu materiału dźwiękowego analizie komputerowej za pomocą funkcji dostępnych w programie Praat (Boersma, Wenink 2005). Należy przy tym zaznaczyć, iż intonacja należy do złożonych zjawisk percepcyjnych, których charakter nie został jak dotąd precyzyjnie określony. Trudno bowiem, na przykład, jednoznacznie ustalić, ile istotnych dla interpretacji wypowiedzi wysokości tonów 
ucho ludzkie potrafi wyróżnić. Program komputerowy natomiast analizuje częstotliwość podstawową $F_{0}$ w funkcji czasu, której nie można w pełni utożsamiać z intonacją percypowaną przez człowieka (Karpiński 2006:57). Graficzną reprezentację przebiegu częstotliwości podstawowej stanowi intonogram. Linia reprezentująca intonację wypowiedzi nie jest ciagła, ponieważ częstotliwości podstawowej nie można wyekstrahować z segmentów bezdźwięcznych, jakimi są niektóre spółgłoski. W tym właśnie aspekcie przejawia się owa sprzeczność z naszym postrzeganiem melodii wypowiedzi jako przebiegu ciagłego. Przebieg intonogramu zawiera drobne ugięcia reprezentujące pewne zjawiska z dziedziny mikroprozodii, których z kolei człowiek nie rejestruje (Karpiński 2006:58). Istnieje jednak możliwość modelowania przebiegu konturu intonacyjnego, tak aby intonogram zawierał elementy relewantne percepcyjnie lub językowo. W procesie dokonywania korekt bezwzględnie konieczna staje się analiza odsłuchowa. Program Praat oferuje możliwość ekstrakcji z sygnału mowy przebiegu częstotliwości podstawowej i stworzenia graficznej reprezentacji zmian owej częstotliwości w czasie. Ekstrakcja tonu podstawowego opiera się na udoskonalonej przez autora programu metodzie autokorelacji (Boersma 1993; Boersma, Wenink 2005). Program pozwala na dokonywanie ingerencji w wiele parametrów algorytmu, jak również funkcję usuwania $\mathrm{z}$ serii wyznaczonych wartości $F_{0}$ skoków częstotliwości (podwojenia lub społowienia) oraz wygładzenia konturu w celu wyeliminowania wpływów miroprozodii. Kontur można stylizować, tworząc jego reprezentacje o określonym stopniu precyzji. Przy pomocy tego samego programu można także tworzyć spektrogramy. Niska jakość materiałów poddanych analizie instrumentalnej w przedstawionych tutaj badaniach spowodowała jednak, że informatywność spektrogramów jest ograniczona. Służą one zasadniczo ogólnej orientacji w strukturze segmentalnej wypowiedzi.

\section{Cele badawcze}

Słowo w tekście dramatu i słowo w spektaklu teatralnym funkcjonuje w odmienny sposób. W pierwszym przypadku nadawcą komunikatu jest autor tekstu, w drugim przypadku reżyser oraz aktor, scenograf, muzyk poprzez których reżyser się wypowiada (Osiński 1967c:125). Poza tym reżyser dokonuje przekładu tekstu dramatu z języka graficznego wypowiedzi literackiej na język foniczny wypowiedzi teatralnej. W tekście utrwalonym graficznie poszczególne elementy dźwiękowe istnieją bowiem tylko w sposób potencjalny, podczas gdy w wypowiedzi teatralnej uzyskują realne brzmienie dzięki specyficznej artykulacji realizowanej przez aktora. Wygłoszenie tekstu przeanalizowałam na poziomie wyrazu i zdania (frazy).

W języku polskim ogólnym akcent posiada trzy wymiary: wysokościowy (melodyczny), rytmiczny i dynamiczny (Pawłowski 2002:287). W przypadku mowy silnie nacechowanej emocjonalnie, tak jak ma to miejsce np. w teatrze, akcent bywa dodatkowo uwikłany w relacje z artykulacją i barwą wymowy (Pawłowski 2002:287). Akcenty zazwyczaj uzupełniają się nawzajem, tworząc określoną całość. W celu zaakcentowania danego słowa używa się nie tylko akcentu dynamicznego, ale podnosi się lub obniża wysokość głosu przy jego wymawianiu, dodatkowo wydłużając bądź skracając samogłoski lub rzadziej spółgłoski. Ta sama zasada odnosi się do realizacji akcentu zdaniowego.

Należy jeszcze raz podkreślić, że dostępny materiał jest ograniczony ilościowo (dostępne są tlko pojedyncze nagrania poszczególnych spektakli) i jakościowo, w związku z tym większość analiz musi mieć charakter opisowy odnoszący się do zjawisk jednostkowych. Nie sposób przeprowadzić studiów porównawczych i statystycznych, które mogły doprowadzić do jakichś uogólnień.

Wybór określonych fragmentów wypowiedzi aktorów był podyktowany chęcią ukazania sposobów realizownia przez nich akcentów melodycznych i rytmicznych, których przebiegi dalece odbiegają od tych używanych $\mathrm{w}$ mowie potocznej $\mathrm{i}$ jednocześnie decydują o umuzycznieniu wygłoszenia. Wybrano też fragmenty, między którymi zachodzi relacja zdwojenia częstotliwości, przywołująca na myśl jedną z technik kompozytorskich, polegających na powtarzaniu przez głosy wokalne bądź instrumentalne jakiejś melodii (czasami nieco zmodyfikowanej) w relacji oktawy lub innego interwału. 


\section{Analiza}

\subsection{Tragiczne dzieje Doktora Fausta wg Christophera Marlow'a}

Fragment sceny rozmowy Fausta z Aniołami:

Tekst Anioła I: Porzuć o Fauście tę magię przeklęta, duszę ci kusi, nie zaglądaj do niej.

Na glowe twoja ściaga gniewy boże, wgtębiaj się w pismo, tamto jest

bluźnierstwo.

Tekst Anioła II: Postępuj dalej w stynnej sztuce zawierajacej cały skarb natury.

Bądź tym na ziemi, czym Jowisz na niebie, panem wladcq wszelakich

żywiołów.

Narrator: Teraz w lesie, teraz Faust czyni swe zaklęcia, aby się przekonać.

Zawiste duchy widzqc jego modty i te ofiary postuszne mu będq.

Poniższe ryciny prezentują intonogramy i spektrogramy wypowiedzi poszczególnych postaci.
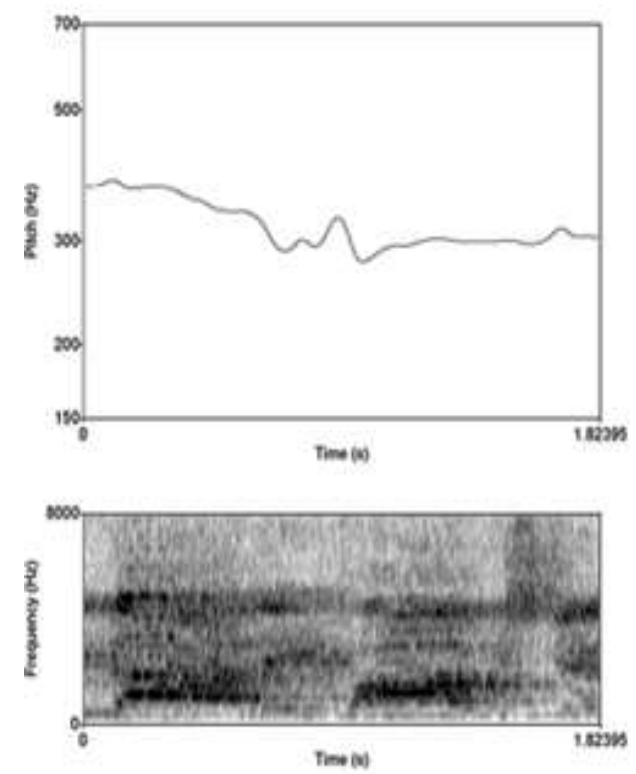

Ryc. 1. „dalej Fauście”
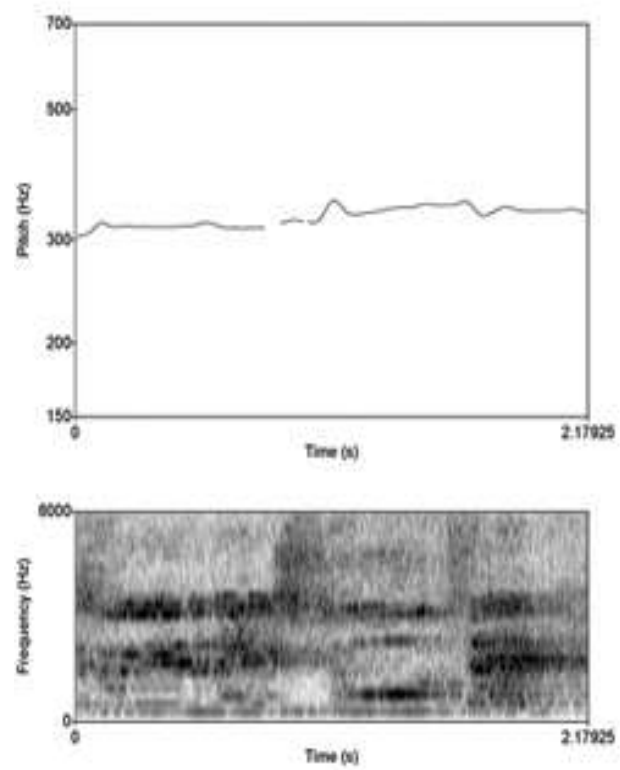

Ryc. 2. ,w stynnej sztuce”

Na ryc.1 zauważamy, że pierwsze sylaby obu wyrazów ulegają wzdłużeniu i zaakcentowaniu dynamicznemu, co widać $\mathrm{W}$ intensywności energii zarejestrowanej na spektrogramie. W miejscu połączenia tych dwóch wyrazów pojawią się niedostrzegalne odsłuchowo zaburzenia mikroprozodyczne, być może związane ze strukturą segmentalną wypowiedzi. W wymiarze czasowym widoczna jest rytmiczna konsekwencja. Pierwsze sylaby cechuje zbliżony iloczas, podobnie jak drugie. W przypadku pierwszej sylaby wyrazu dalej mamy do czynienia z z intonacją opadająca, a w przypadku pierwszej sylaby wyrazu Fauście - z akcentem wypowiedzianym $\mathrm{z}$ intonacją rosnącą. Druga sylabę tego samego wyrazu cechuje już intonacja równa.

Na ryc. 2 obserwujemy chwilowy wzrost częstotliwości podstawowej na samogłosce $e$ oraz jej spadek na samogłosce $u$. Każda z sylab wyrazu sztuce trwa mniej więcej tyle samo, co wyrażenie w stynnej. 

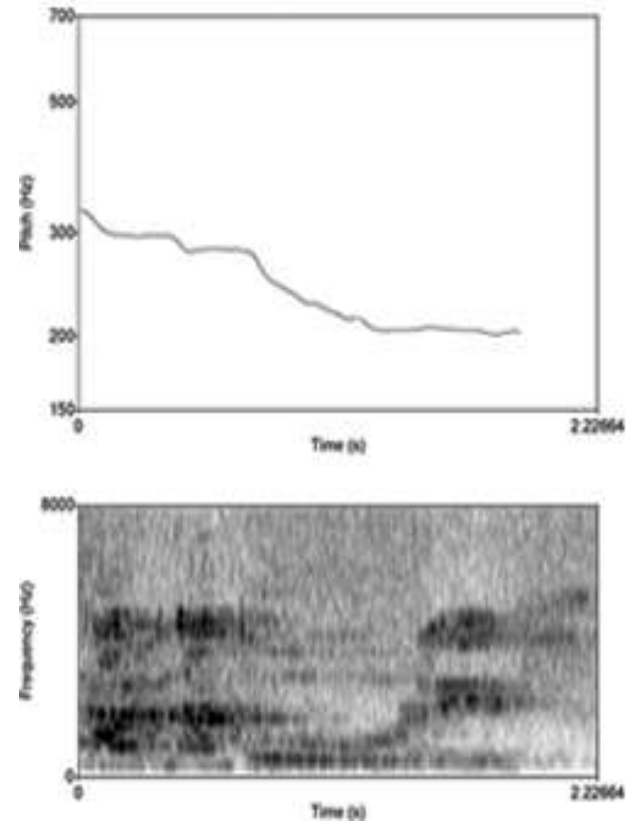

Ryc. 3. , skarb natury"
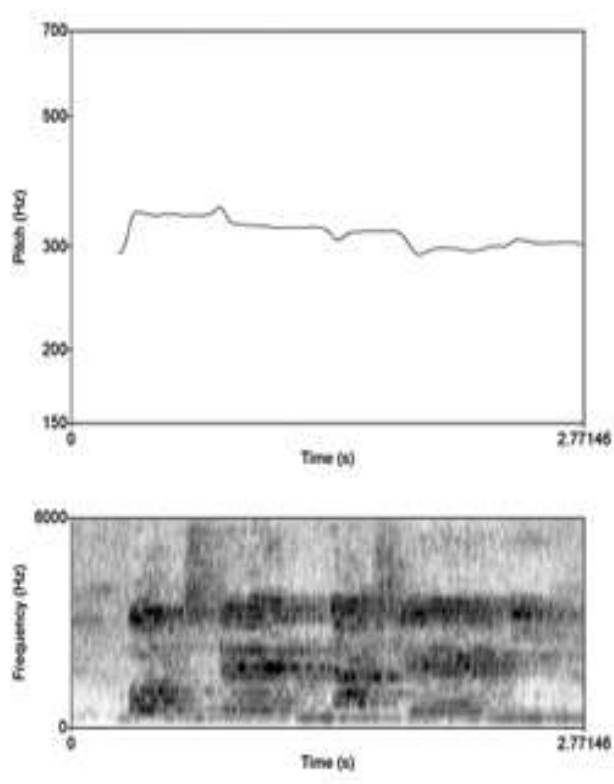

Ryc. 4. „badź tym na ziemi”

$\mathrm{Na}$ ryc. $3 \mathrm{w}$ wyrazie natury widoczne jest wzdłużenie samogłoski $u$ i $y$. Cały ten wyraz wymawiany jest $\mathrm{z}$ intonacją opadającą (na przestrzeni wyrazu $\mathrm{F}_{0}$ spada o około $80 \mathrm{~Hz}$ ). Wyraz skarb wymawiany jest z częstotliwością podstawową około $300 \mathrm{~Hz}$, zaś sylaba na przy $290 \mathrm{~Hz}$. Pozostałe dwie sylaby wyrazu natury zaakcentowane są silnym spadkiem intonacji. Główny akcent przypada jednak na sylabę $t u$, co wyraźnie przejawia się w iloczasie samogłoski /u/. Z kolei na ryc. 4 mamy do czynienia $\mathrm{z}$ akcentuacją opartą na wzdłużeniu przy intonacji równej. Zmiany w konturze intonacyjnym zachodzą głównie w obrębie spółgłosek.
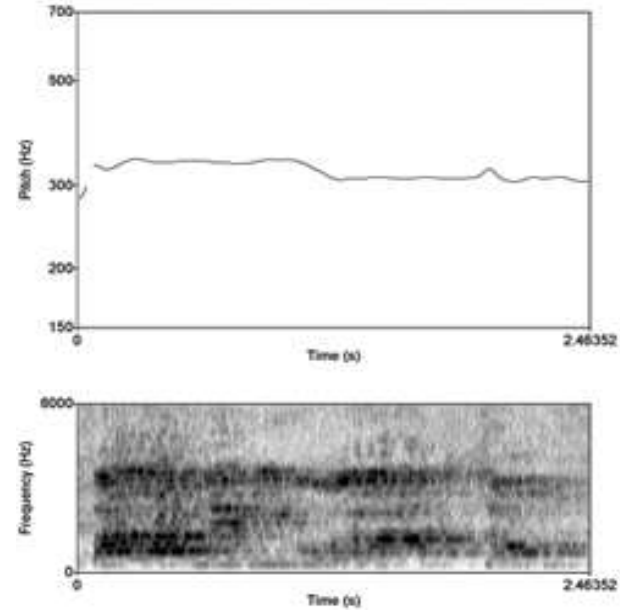

Ryc. 5. „panem i władca”
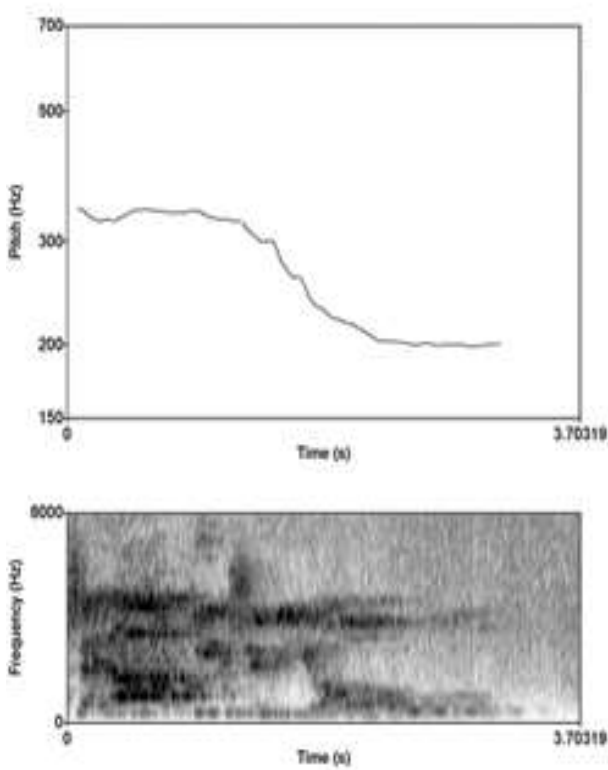

Ryc. 6. „,wszelakich żywiolów”

$\mathrm{Na}$ ryc. $5 \mathrm{w}$ przypadku pierwszego słowa panem zasadniczy akcent przypada na pierwszą sylabę, na samogłosce $e$ intonacja lekko opada do poziomu $300 \mathrm{~Hz}$. Na wysokości ok. $305 \mathrm{~Hz}$ wymawiane jest słowo wtadca $\mathrm{z}$ akcentem na pierwszą sylabę. Zaburzenie równej intonacji 
spowodowane jest najprawdopodobniej sąsiedztwem dwóch spółgłosek: dźwięcznej i zwartoszczelinowej. Czas wypowiedzenia obu słów jest podobny, jak również iloczas sylab akcentowanych .

Na ryc. 6 wyraz wszelakich aktorka wypowiada na wysokości $350 \mathrm{~Hz}$, przy czym pierwsza sylaba (wsze-) jest zrealizowana $\mathrm{z}$ melodią opadająco-rosnącą Akcent główny (dynamiczny i iloczasowy) przypada na drugą sylabę (jej jądrem jest samogłoska /a). Pierwsze słowo trwa ok. jednej sekundy. Drugie ponad dwie sekundy. W wyrazie żywiołów intonacja opada na pierwszych dwóch sylabach, na trzeci (łów) aktorka realizuje z intonacją równą. Obserwuje się znaczący spadek częstotliwości o $140 \mathrm{~Hz}$ w obrębie dwóch piewrszych sylab w/w wyrazu.
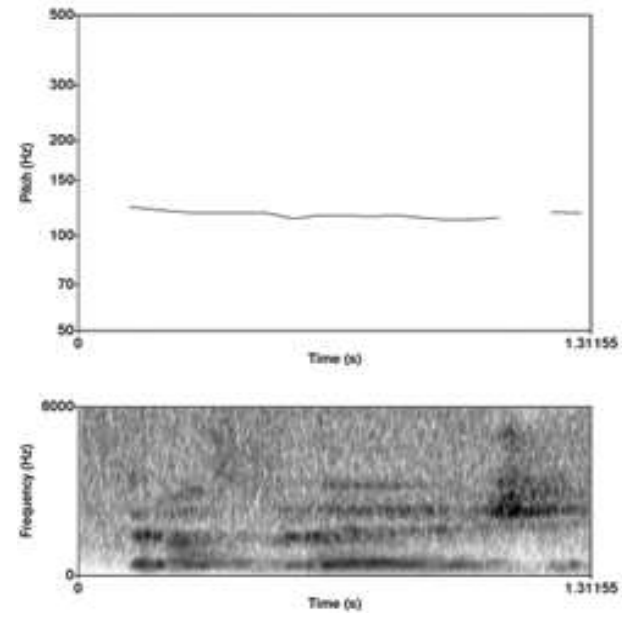

Ryc. 7. „teraz w lesie”
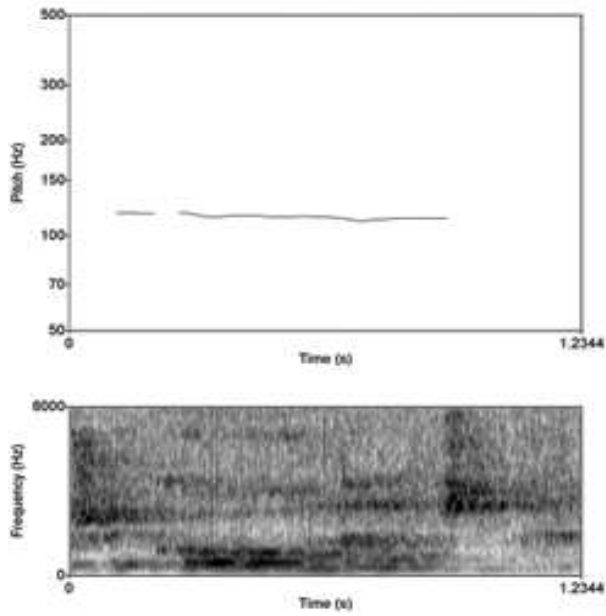

Ryc. 8. „przekonać”

Ryc. 7. obrazuje realizację tekstu wymawianego z intonacją równą z zastosowaniem akcentu dynamicznego i rytmicznego. Na spektrogramie możemy dostrzec cztery pasma formantów, które pomagają nieco wyobrazić sobie przebieg wypowiedzi aktora. Widoczne na początku silniej zaczernione, krótkie pasmo dwóch formantów (trzeci i czwarty formant jest bardzo słabo widoczny) odnosi się do pierwszej sylaby wyrazu teraz. Druga sylaba natomiast została nieco wydłużona przez aktora, ale jednocześnie wymówiona z mniejszą energią. Dłuższe pasmo lepiej widocznych, czterech formantów odnosi się do wyrazu lesie, w szczególności do jego pierwszej sylaby z samogłoską $e$. Ostatni, najbardziej intensywnie zaczerniony segment obrazuje wymowę samogłosek $i$ oraz $e$ drugiej sylaby wyrazu. W wymiarze czasowym ponownie obserwujemy zasadę podwojenia czasu trwania drugiego $\mathrm{z}$ wyrazów w stosunku do pierwszego.

W kolejnym przykładzie (ryc. 8) dostrzeżemy, że akcent dynamiczny i czasowy przypada w wyrazie przekonać na sylabie paroksytonicznej. Czas trwania tego członu jest podwojony względem czasu trwania pozostałych dwóch sylab. To samo zjawisko dostrzegamy w następnym przypadku - ryc. 9 . 

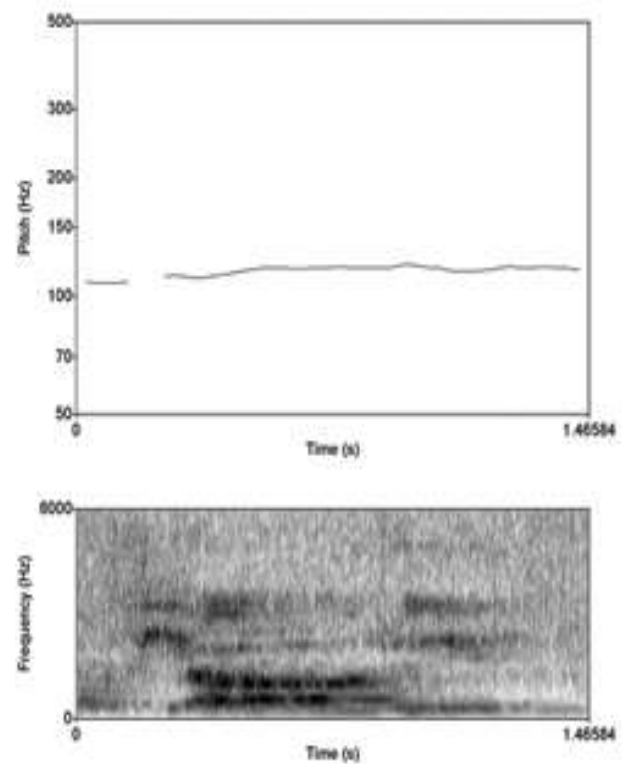

Ryc. 9."ofiary"

Zdania, które wypowiada Anioł I, są podzielone na dwie sekwencje, z których każdą cechuje intonacja opadająca. Na ryc. 10 widzimy, że drugi człon zdania rozpoczynający się od słowa dusze wypowiadany jest wyżej o ok. $90 \mathrm{~Hz}$. Oba człony natomiast cechuje intonacja opadająca.

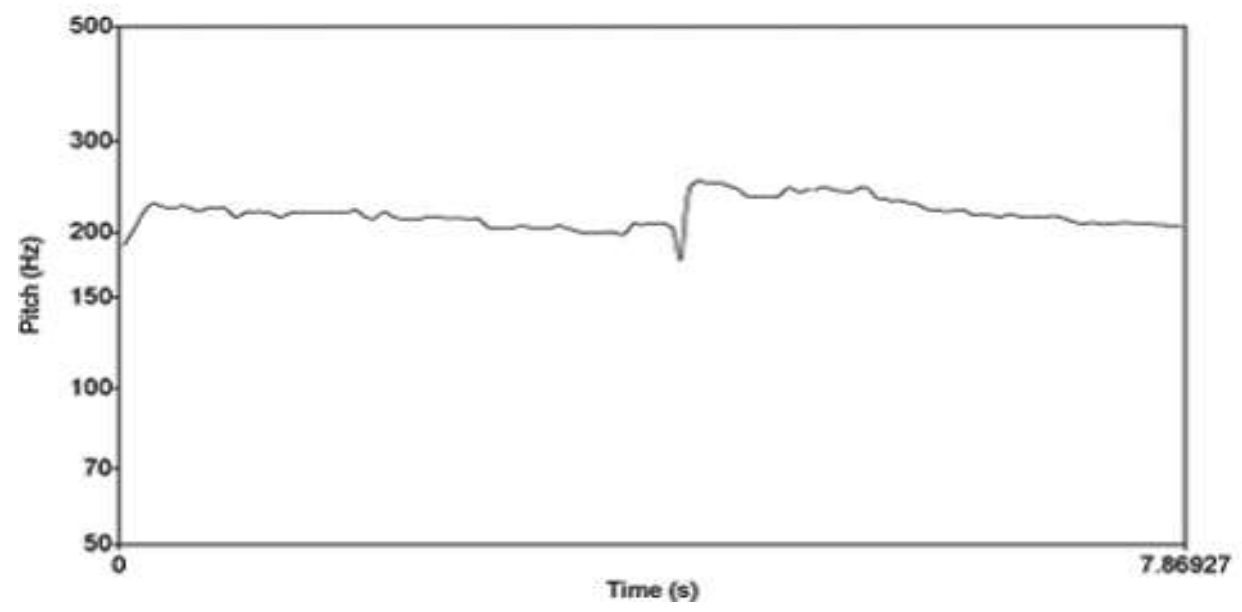

Ryc. 10. „porzuć o Fauście tę magię przeklęta, duszę ci kusi nie zagladaj do niej” 


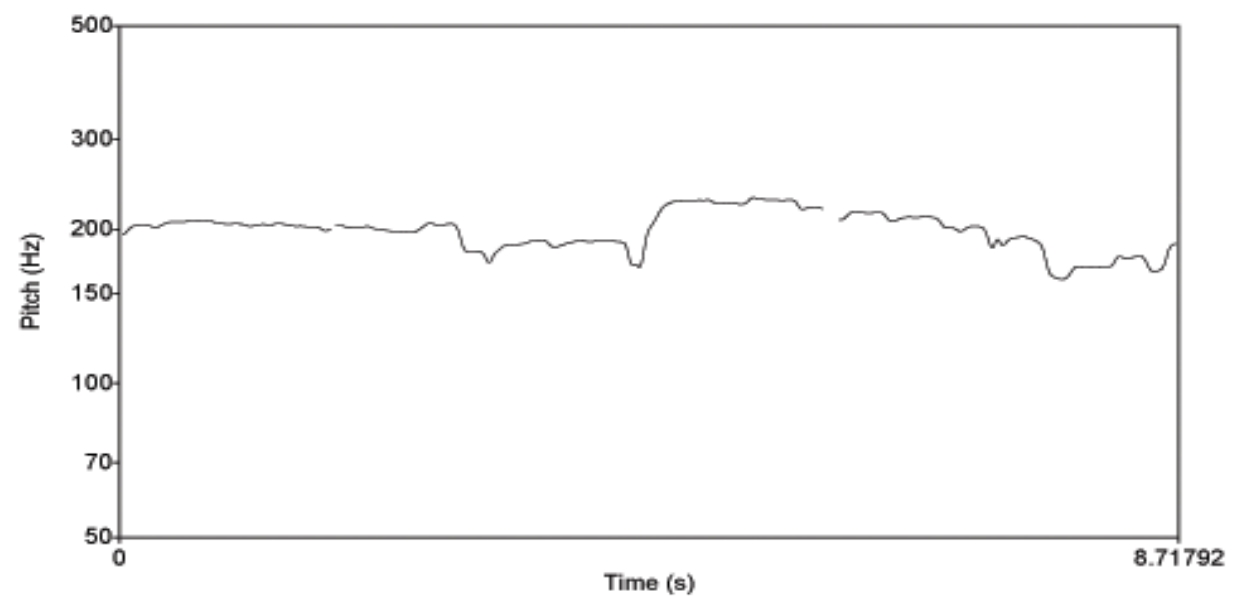

Ryc. 11. „, na głowę twoja ściaga gniewy boże, wgłębiaj się w pismo tamto jest bluźnierstwo”

Intonacja opadająca występuje także w zdaniu, którego intonogram przedstawiono na ryc. 11. W tym przypadku drugi człon zdania ponownie wypowiadany jest wyżej, tutaj o ok. $50 \mathrm{~Hz}$. Zdania wypowiadane przez Anioła II cechuje zróżnicowana intonacja. Jej specyfikę obrazują dwie kolejne ryciny -12 i 13 .

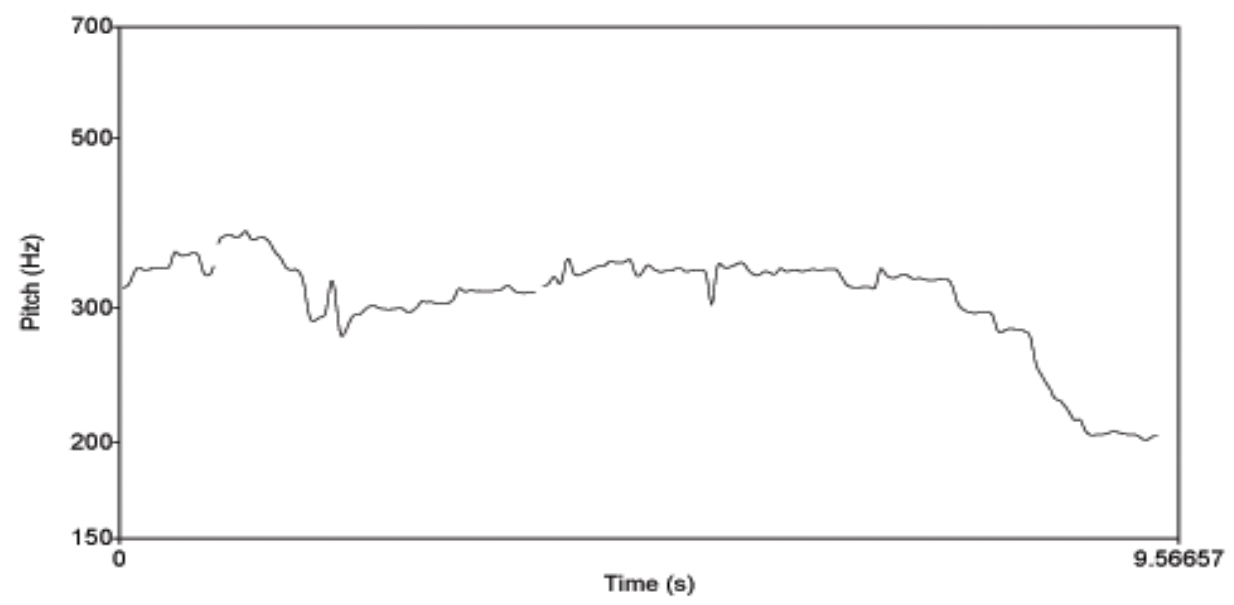

Ryc. 12. „postępuj dalej w stynnej sztuce, zawierajacej cały skarb natury”

Jak widać na ryc. 12, drugi człon zdania rozpoczynający się od wyrazu zawierajacej nie został przez aktorkę zaakcentowany znacząco rosnącą intonacją. $\mathrm{Na}$ uwagę natomiast zasługuje wydłużenie ostatniego wyrazu - natury i dodatkowe podkreślenie go go intonacją wyraźnie opadającą. To samo zjawisko dostrzeżemy na następnej rycinie - 13 na wyrazie żywiołów. 


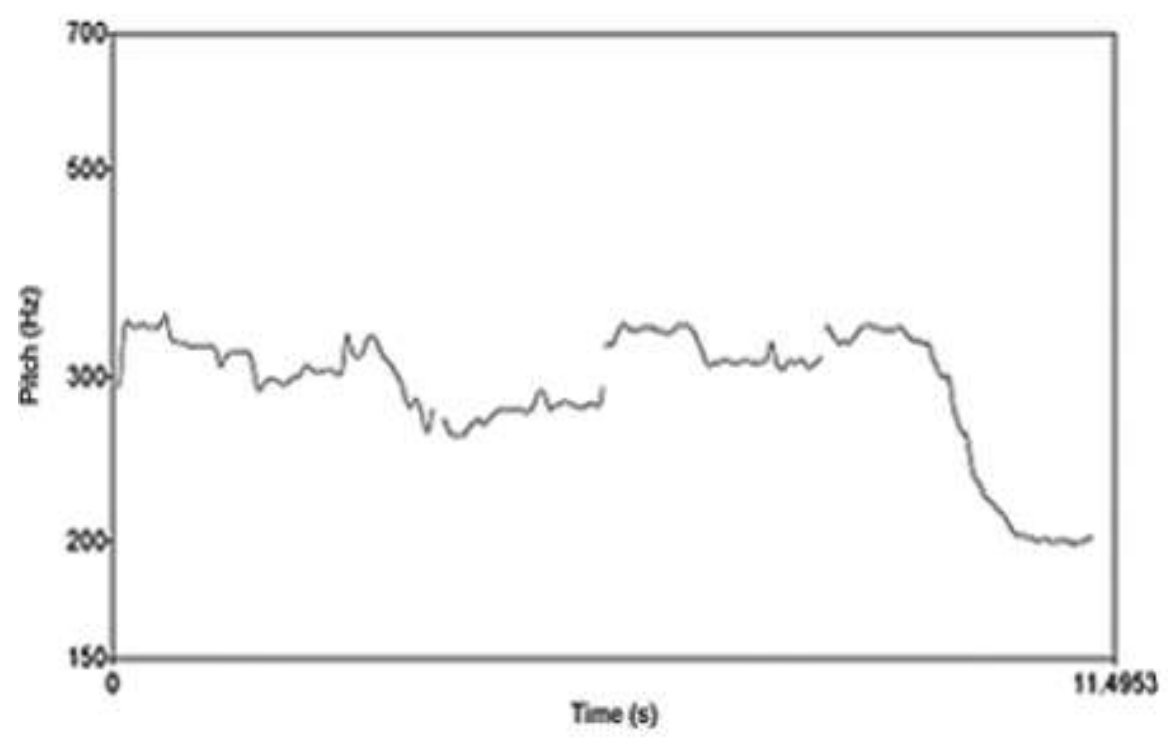

Ryc. 13. „bqdź tym na ziemi czym Jowisz na niebie, panem i władca wszelakich żywiołów”

W przykładzie z ryc. 13 powraca zjawisko podwyższenia częstotliwości podstawowej drugiej części zdania rozpoczynającego się od wyrazu panem. Ten wzrost widoczny jest wyraźnie w połowie intonogramu, w okolicach siódmej sekundy pokazanego przedziału czasowego.

Intonogramy zaprezentowane na ryc. $10,11,12$ i 13 pozwalają także na dostrzeżenie zasady różnicowania poszczególnych postaci dramatu poprzez stosowanie odmiennego zakresu częstotliwości dla każdej z osobna.

Analiza strategii intonacji realizowanej na przestrzeni całych zdań pozwala zaobserwować pewną regularność. Konsekwencja $\mathrm{z}$ jaką poszczególni aktorzy traktują słowo dowodzi tego, iż intonacja odgrywa też istotną rolę różnicująca postaci dramatu. $\mathrm{Na}$ uwagę zasługuje równa intonacja Narratora przedstawiona na ryc. 14 i 15, będąca prawdopodobnie odzwierciedleniem jego obiektywizmu, braku zaangażowania emocjonalnego, ale też przywołująca na myśl monotonną intonację modlących się wiernych np. w trakcie nabożeństw litanijnych w obrządku Kościoła Katolickiego. Taki zabieg intonacyjny stanowiłby jeden $\mathrm{z}$ wielu przykładów odwołania się Grotowskiego i jego zespołu aktorskiego do katolickiej tradycji kościelnej, nie tylko w ramach omawianego przedstawienia, ale i w kolejnych przedstawieniach.

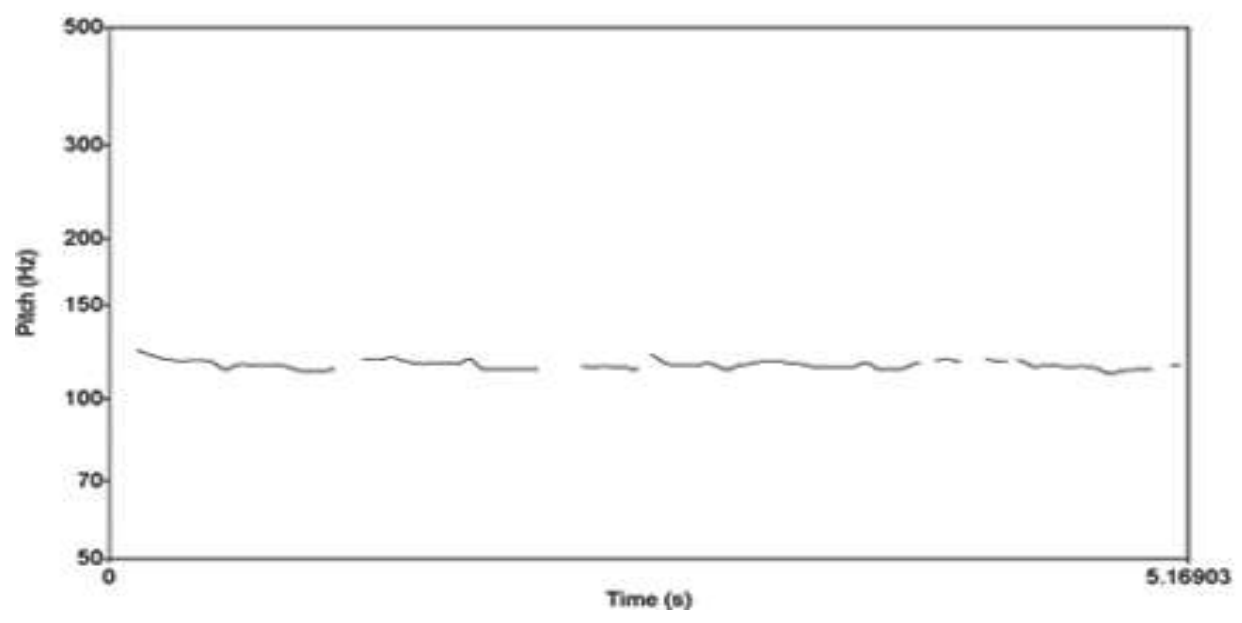

Ryc. 14. „teraz w lesie, teraz Faust czyni swe zaklęcia, aby się przekonać” 


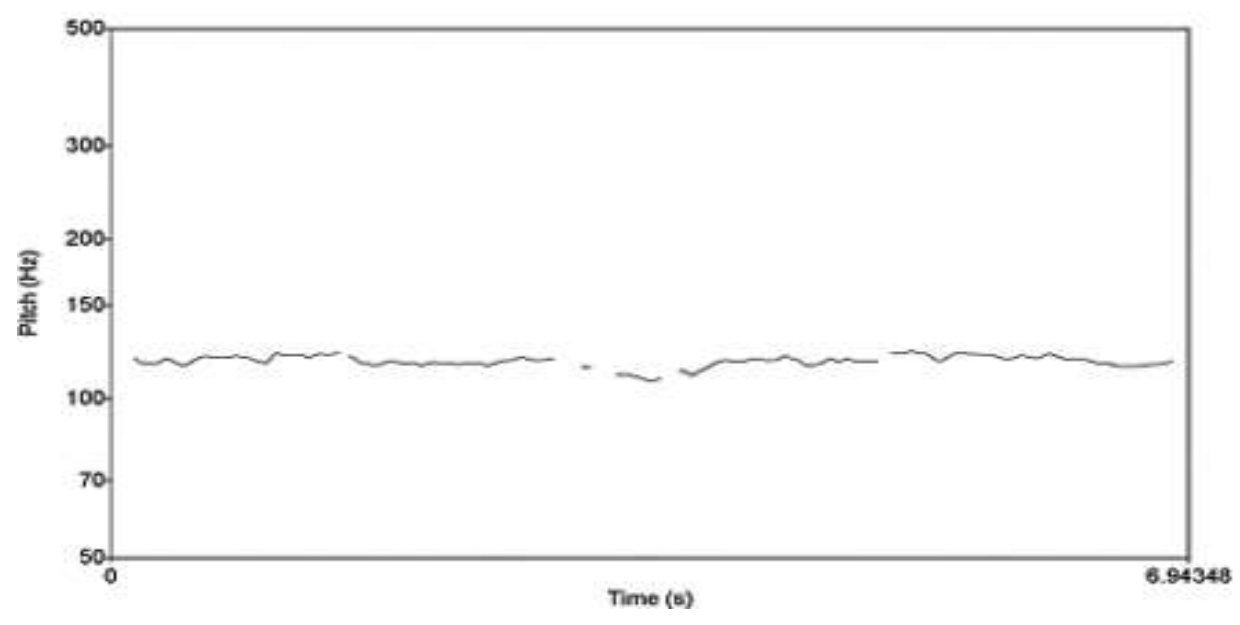

Ryc. 15. ,zawiste duchy widzqc jego modty i te ofiary postuszne mu będq”

Intonogramy pozwalają dostrzec zasadę różnicowania częstotliwości dźwięków charakterystycznych dla poszczególnych postaci. Anioł I mówi w zakresie ok. 200 do $250 \mathrm{~Hz}$, między a3 i h3 (trzykreślnym), Anioł II operuje zakresem bardziej zróżnicowanym, ale koncentrującym się na średniej wysokości $300 \mathrm{~Hz}$ (z charakterystycznym spadkiem intonacji do $200 \mathrm{~Hz}$ na ostatnich wyrazach zdań), a więc zakresem od $d 4$ do e4 (czterokreślnego) ze spadkiem do okolic a3. Narrator z kolei operuje wyrównanym zakresem - ok. $130 \mathrm{~Hz}, c 3$. Gdybyśmy ujęli (w przybliżeniu oczywiście) poszczególne wypowiedzi postaci w relacjach interwalicznych, to między Aniołem I i II uzyskalibyśmy interwał kwinty, a między Aniołem II i Narratorem - septymy.

\subsection{Akropolis wg Stanisława Wyspiańskiego}

Podobne zjawiska intonacyjne dostrzeżemy w realizacji spektaklu Akropolis. Tutaj też mamy do czynienia $\mathrm{z}$ całą gamą środków akcentuacyjnych, polegających na wydłużaniu sylab i wygłaszaniu ich z użyciem intonacji rosnącej, opadającej, rosnąco-opadającej i opadającorosnącej. Oto monolog Narratora zapowiadającego starotestamentową historię:

W dalekim Kanaan starozakonna historia Jakuba.

Nasampierw scena, jako ojciec woła

syna starszego i rzekt: niech sposobi

koźle - a za nim ten z powrotem zdoła,

już brat go ubiegt. Więc indziej sen stugi

bożego w Bethel o orszak ów dtugi

aniołów, jako ida po drabinie.

Jak mu Bóg kazal na śnie, tak on w czynie to spetnit wstawszy. Zaś ówdzie spotkanie

z Rachela, gdy się owce u źródet poja.

Jak ja objat uściskiem i nazywat swoja siostra. Więc Laban go do dom przyjmuje

i starszq córkę dać mu obiecuje. 

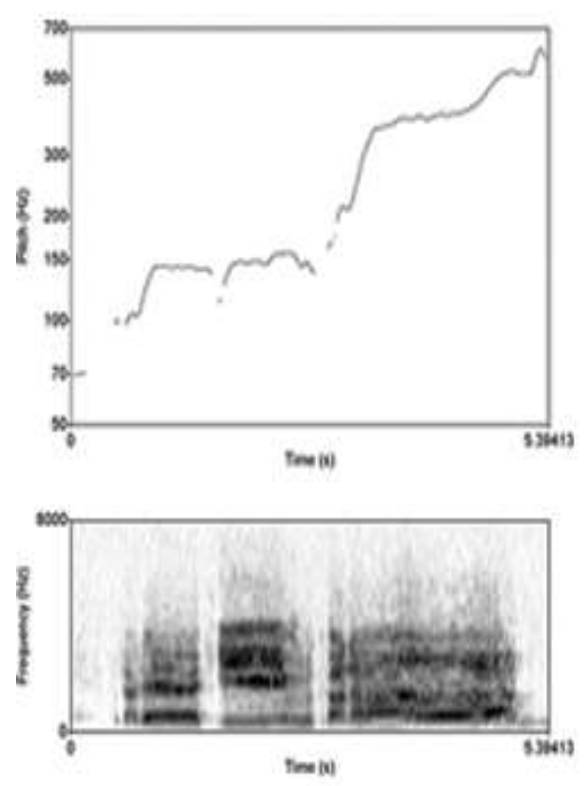

Ryc. 16. ,w dalekim Kanaan”
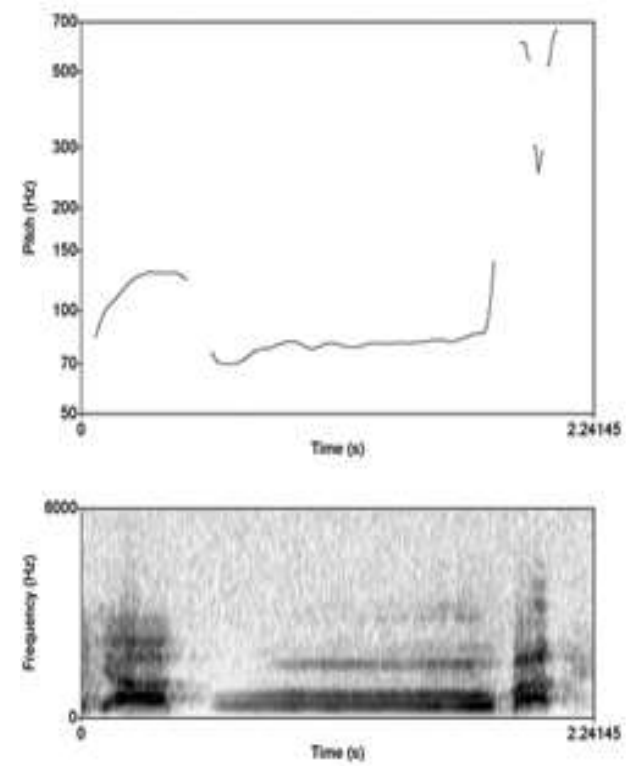

Ryc. 17. "starozakonna historia Jakuba"

W wyrazie dalekim na ryc. 16 znacznemu wzdłużeniu uległa sylaba -le-. Można ten zabieg odczytywać jako metaforę rozległej przestrzeni (odległości). Wyraz ten jako całość aktor wygłosił $\mathrm{z}$ intonacją nieznacznie rosnącą. $\mathrm{O}$ wiele wyższy skok częstotliwości podstawowej dostrzeżemy na słowie Kanaan, w obrębie którego spada ona z ok. $150 \mathrm{~Hz}$ (okolice d3) do $600 \mathrm{~Hz}$ (okolice d5). Funkcją tego zabiegu intonacyjnego jest zapewne podtrzymanie uwagi słuchacza przed wygłoszeniem dalszej części zdania - starozakonna historia Jakuba. Na ryc. 17 widoczne jest z kolei wzdłużenie wyrazu Jakuba, a dokładnie sylaby $k u$ i realizacja intonacji równej. Aktor zastosował tutaj akcent melodyczny na sylabie $b a$. Intonogram w omawianym segmencie zawiera błąd związany ze zdwojeniem częstotliwości w końcówce wykresu. W analizie powyższego przykładu nie można było zastosować funkcji niwelującej tego rodzaju zjawiska, ponieważ dochodziło do całkowitego zniekształcenia konturu całego wyrażenia. Intonogram w tej postaci, jaką prezentuje ryc. 17, odzwierciedla prawidłowy przebieg wygłoszenia., w którym ostatni dźwięk osiaga wysokość ok. $600 \mathrm{~Hz}$ (ok. d5). Zastosowanie przez aktora tego samego zabiegu intonacyjnego świadczy o jego świadomie realizowanej strategii. Na uwage zasługuje także wysiłek wokalny, jaki podjął wspomniany aktor w celu osiagnięcia dźwięku wyższego o dwie oktawy.

A oto kolejne przykłady, w których ostatnie wyrazy zdania konsekwentnie ulegają wydłużeniu wraz z zastosowaniem intonacji rosnąco-opadającej o różnym wymiarze. Przebieg intonacyjny całej wypowiedzi jest zróżnocowany i waha się od ok. 100 do $300 \mathrm{~Hz}$. Ryciny 18-22 prezentują te wyrazy, w których obserwuje się kontury intonacyjne o relatywnie szerokim zakresie częstotliowści. Na wyrazach koźlę, ówdzie i siostra (ryc. 18-20) obserwujemy podobne kontury intonacyje (o oczywiście różnych zakresach), ale funkcjonujące w tym kontekście jako swoiste figury retoryczne. Ryciny 21 i 22 pokazują, w jaki sposób aktor, poprzez ten sam akcent melorytmiczny, wzmocnił foniczną (w tym też rytmiczną) cechę tekstu - rym. 

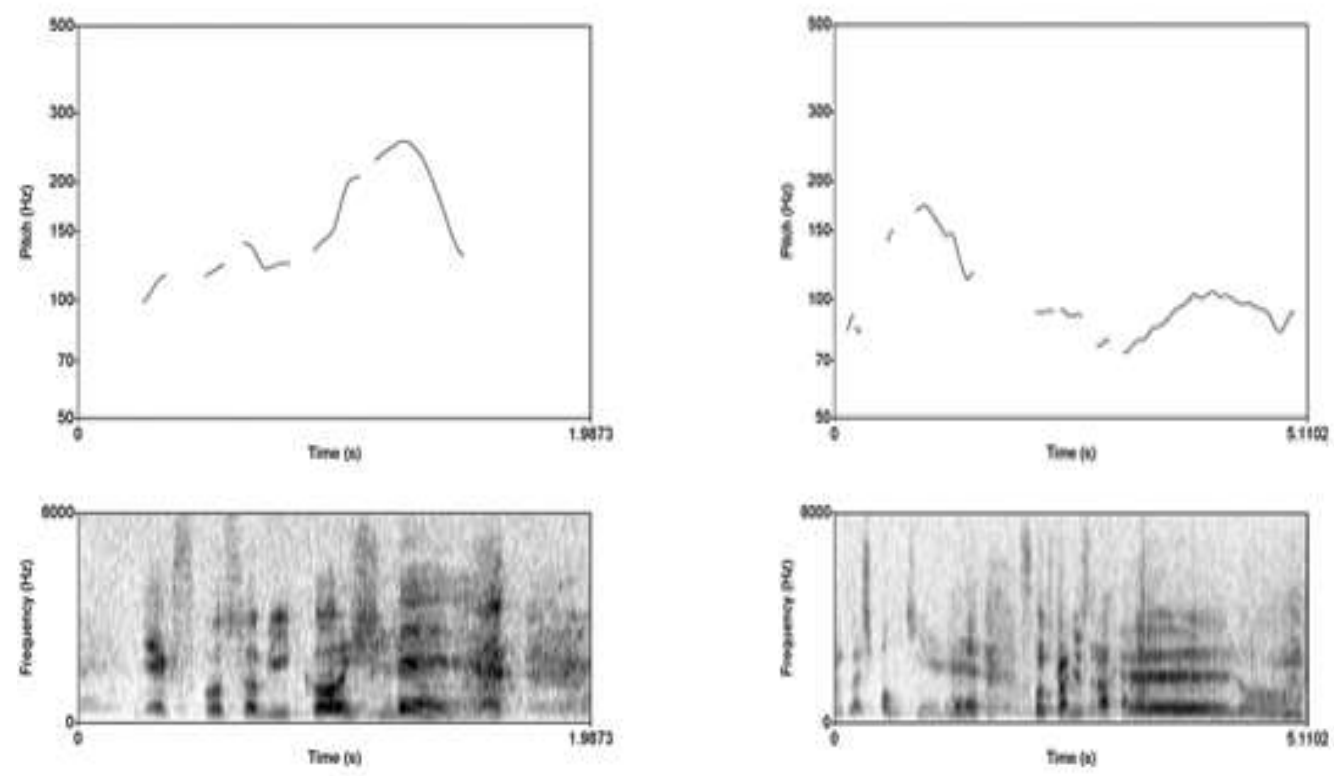

Ryc. 18. „,niech sposobi koźle”,

Ryc. 19. „zaś ówdzie spotkanie z Rachelq"

Na ryc. 18 zaakcentowaniu melodycznemu uległo słowo koźlę. Akcent dynamiczny przypadł na pierwszą sylabę wyrazu. Na 19 ryc. wspomniane akcenty przypadają na słowa ówdzie (kontur intonacyjny rosnąco-opadający od $100 \mathrm{~Hz}$ poprzez $190 \mathrm{~Hz}$, do $110 \mathrm{~Hz}$ ) oraz wyrażeniu z Rachela, realizowanym na zdecydowanie niższej częstotliwości (od $70 \mathrm{~Hz}$ poprzez 100 do ok. $80 \mathrm{~Hz}$ ). Tekst wypowiedziany został jasnym, miękkim głosem sugerującym rozkosz spotkania. Zauważalna jest także w analizie odsłuchowej zwiększona dynamika podczas wygłoszenia tekstu.

Analogiczne strategie prezentują kolejne intonogramy i spektrogramy z przykładami akcentów realizowanych z udziałem intonacji rosnąco-opadajacych, rosnących i równych.
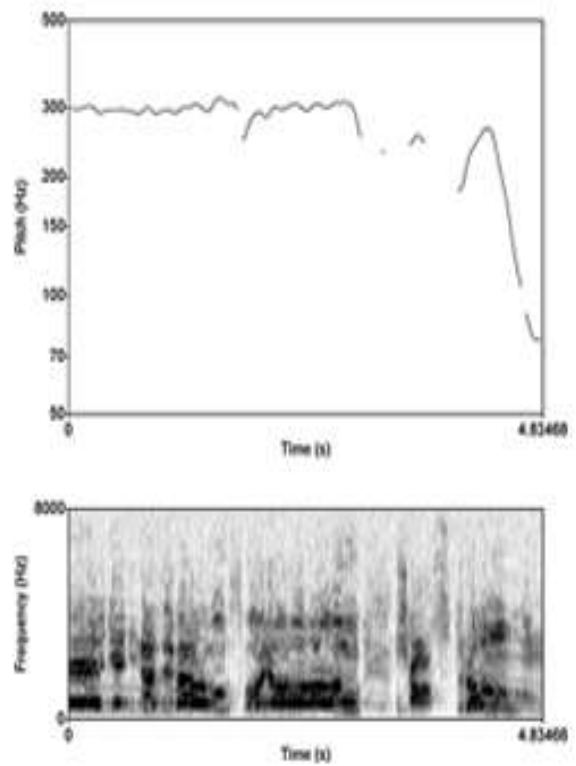

Ryc. 20. „, nazywat swojq siostra”
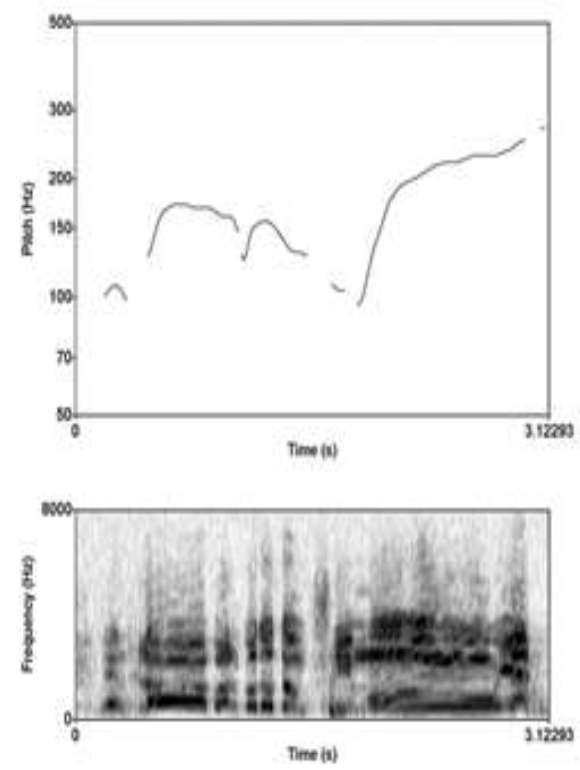

Ryc. 21. „więc Laban go do dom przyjmuje" 

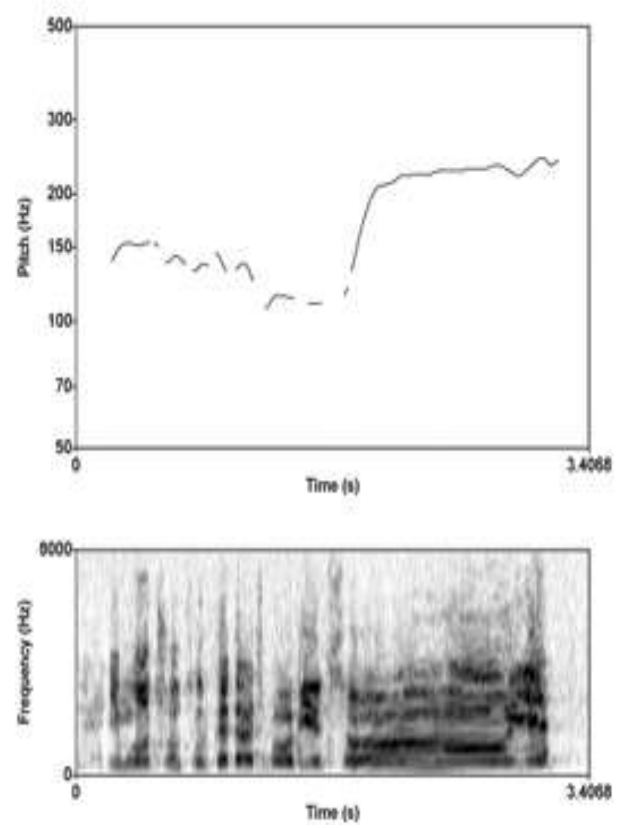

Ryc. 21. „i młodsza córkę dać mu obiecuje”

Podobne zjawisko o charakterze instrumentacyjnym ma miejsce w partii Jakuba. Aktor akcentuje ostatnie wyrazy każdej sekwencji, a w nich akcent główny przy pomocy intonacji rosnąco-opadającej. Dodatkowo akcent poboczny ulega wydłużeniu. Realizacja rosnącoopadającego konturu za każdym razem ulega drobnej modyfikacji. Dla słuchacza jednak istotniejsza jest regularna powtarzalność określonej figury melo-rytmicznej, na której wypowiedziane jest ostatnie słowo frazy, uwypuklająca nie tylko cechy foniczne tekstu, ale i jego rytm.

Oto fragment monologu Jakuba ze sceny aktu III tekstu dramatycznego, opartej na tekście biblijnym opisującym sen o drabinie wznoszącej się ku niebu. Poniższy tekst mówi o aniołach. Aktor wygłasza ten tekst wykorzystując głównie rezonator krtaniowy "rezonator krtaniowy" (zgodnie z terminologią Grotowskiego).

.Tekst: I przystaja na stopniach, $\boldsymbol{i}$ idq,

Dalmatyk wstrzqsajac egida.

I przystaja, i zstępuja ku bronie,

W szat dtugich strojnym obronie.

I przystaja, i zstęuja ku bramie,

I nad śpiacym każdy wznosi ramie. 

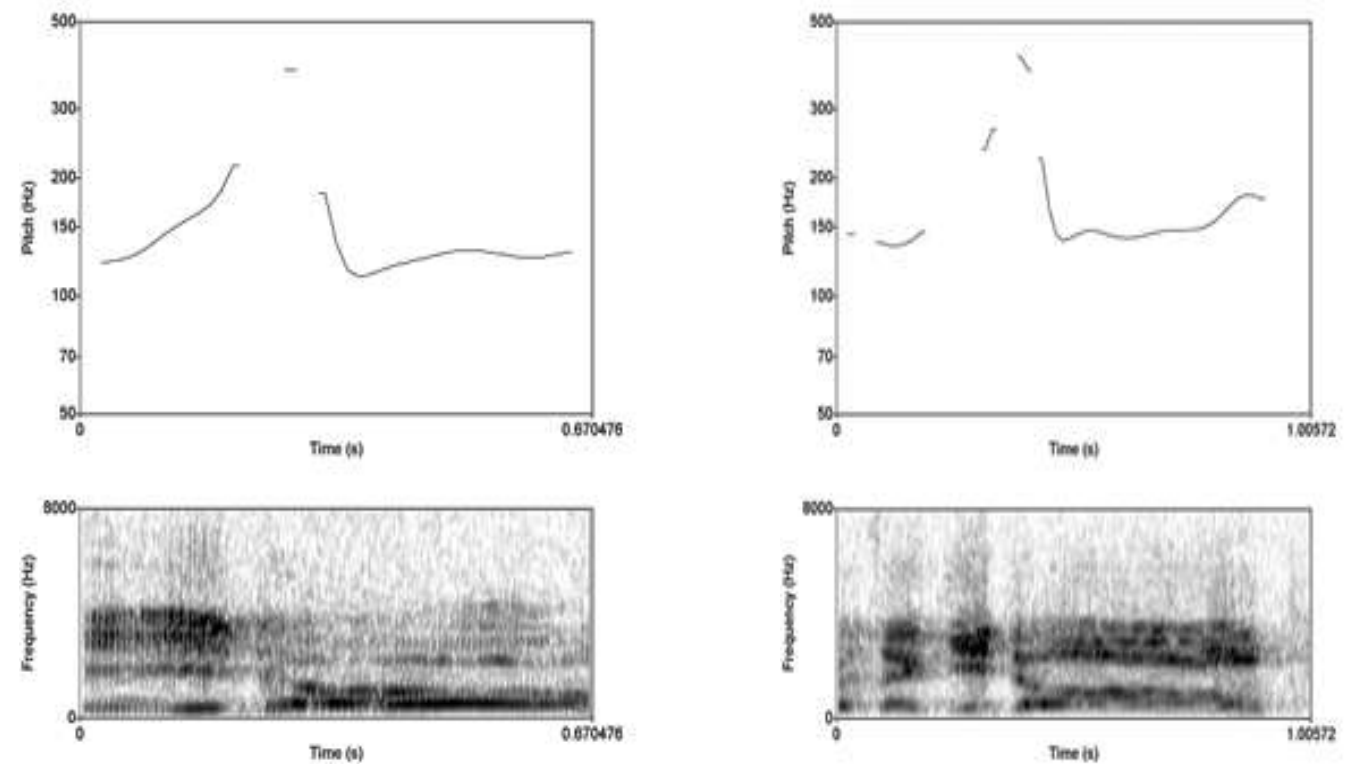

Ryc. 23. ,i idq”

Ryc.24. ,pod egida”
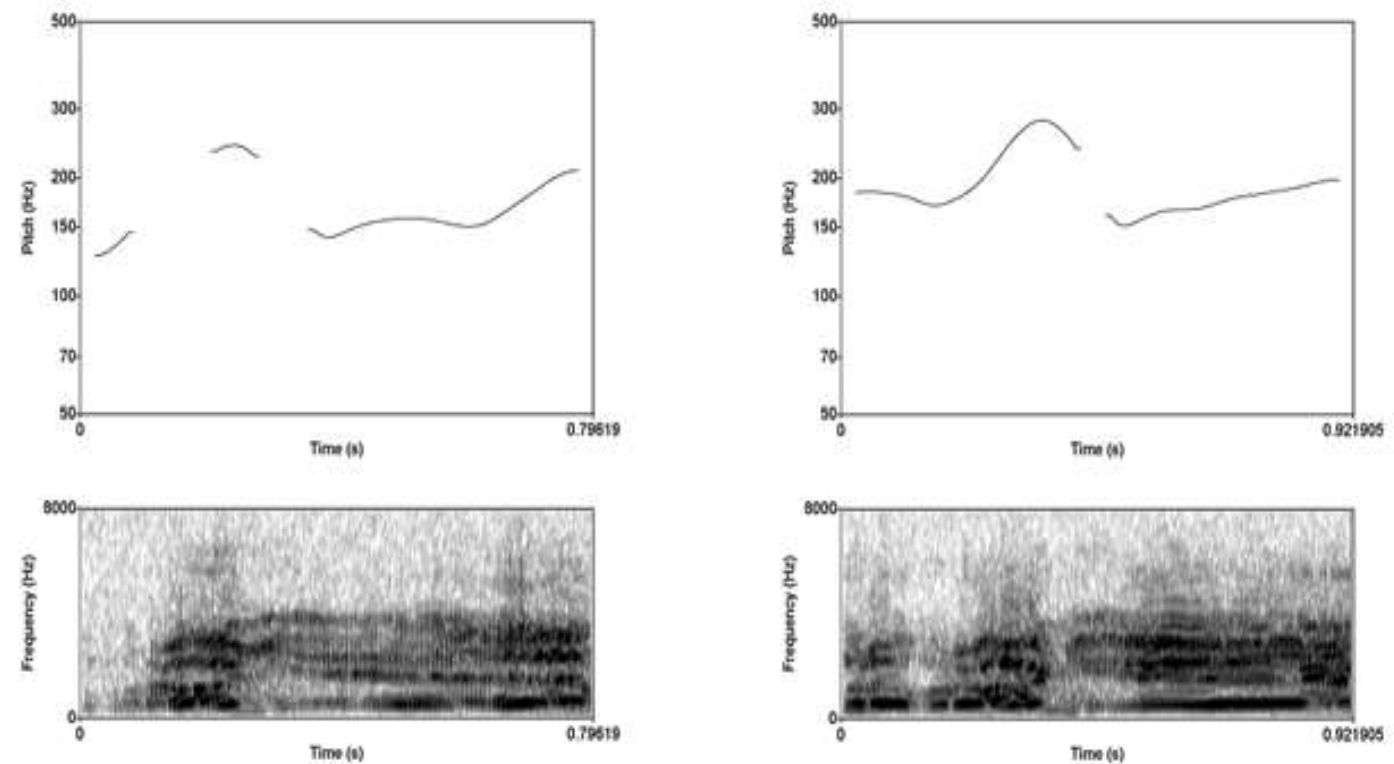

Ryc. 25. „bronie”

Ryc. 26. „obronie” 

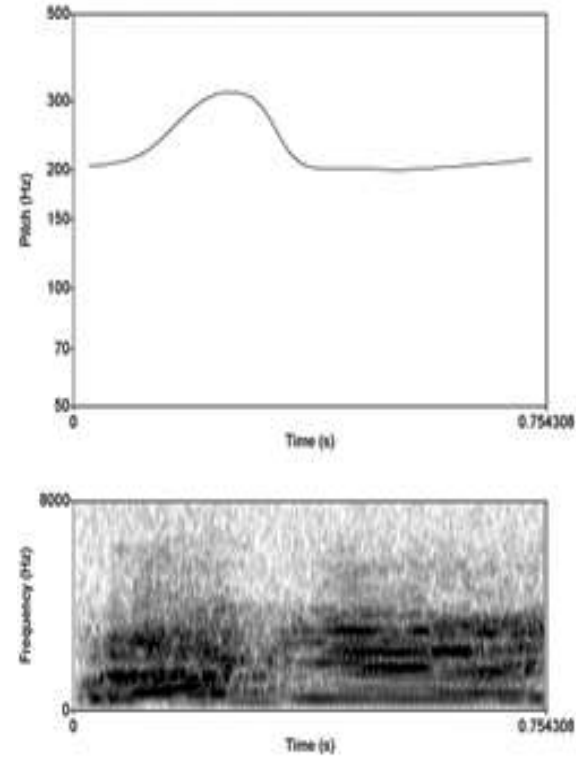

Ryc. 27. „bramie”
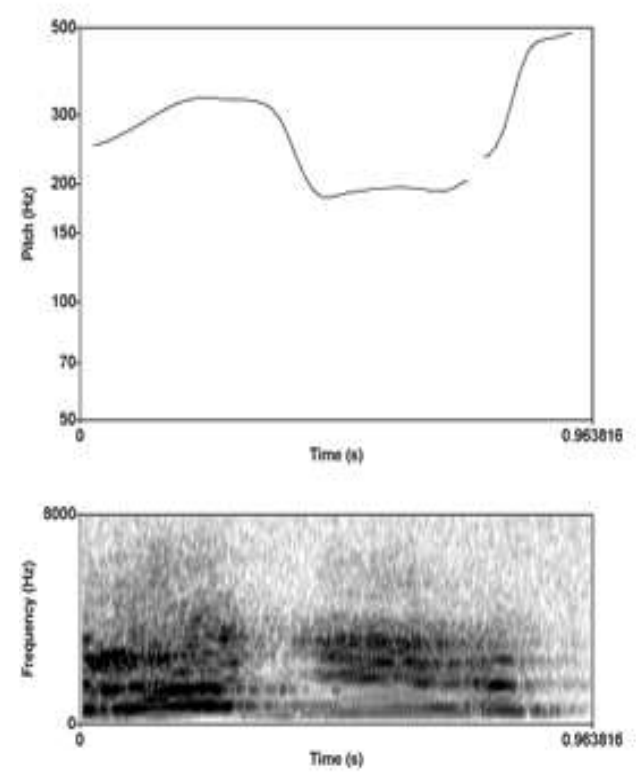

Ryc. 28. „ramie”"

W kontekście omawiania powyższych przykładów (rycin 23-28) trzeba nadmienić, że zastosowany przez aktora sposób melodyczno-rymicznej akcentacji ostatnich słów poszczególnych wersów tekstu można interpretować jako stylizację akcentu jidysz na języku polskim. Jak pamiętamy, w paragrafie 3 niniejszego tekstu, Ludwik Flaszen użył w komentarzu do spektaklu Akropolis terminu „,̇ydłaczenie" (termin ukuty w ramach potocznej praktyki językowej), które odnosiło się do jednego ze sposobów wygłoszenia tekstu przez aktorów. To zjawisko językowe funkcjonuje na poziomie spektaklu jako stylizacja i dostrzegalne jest właśnie w omawianym fragmencie przedstawienia. Dla porównania, można przeanalizować sposób, w jaki akcent jidysz nakłada się na język polski w wypowiedzi rabina Sachy Pecarica ${ }^{2}$. Ryciny 29 i 30 prezentują kontury intonacyjne, których przebieg wydaje sie podobny do konturów intonacyjnych przytoczonych $\mathrm{w}$ rycinach 23-28. Trzeba zaznaczyć, że aktor, posługując się ,żydłaczeniem”, dokonał przerysowania w obrębie swojej intonacji (chodzi o skoki częstotliwości dźwięków). Wypowiedź rabina (wykład na temat Tory) jest dalece mniej ekspresywna (inny jest kontekst sytuacyjny), ale specyfika intonacji wydaje się być podobna. Tego rodzaju zjawisko akcentacyjne można usłyszeć stosunkowo często w przytoczonej wypowiedzi Sachy Pecarica.

\footnotetext{
Nagranie wykładu dr'a Sachy Pcarica m. in. na temat Tory zostało udostępnione przez wydawnictwo Pardes na stronie internetowej www. pardes.pl (01.09.07).
} 

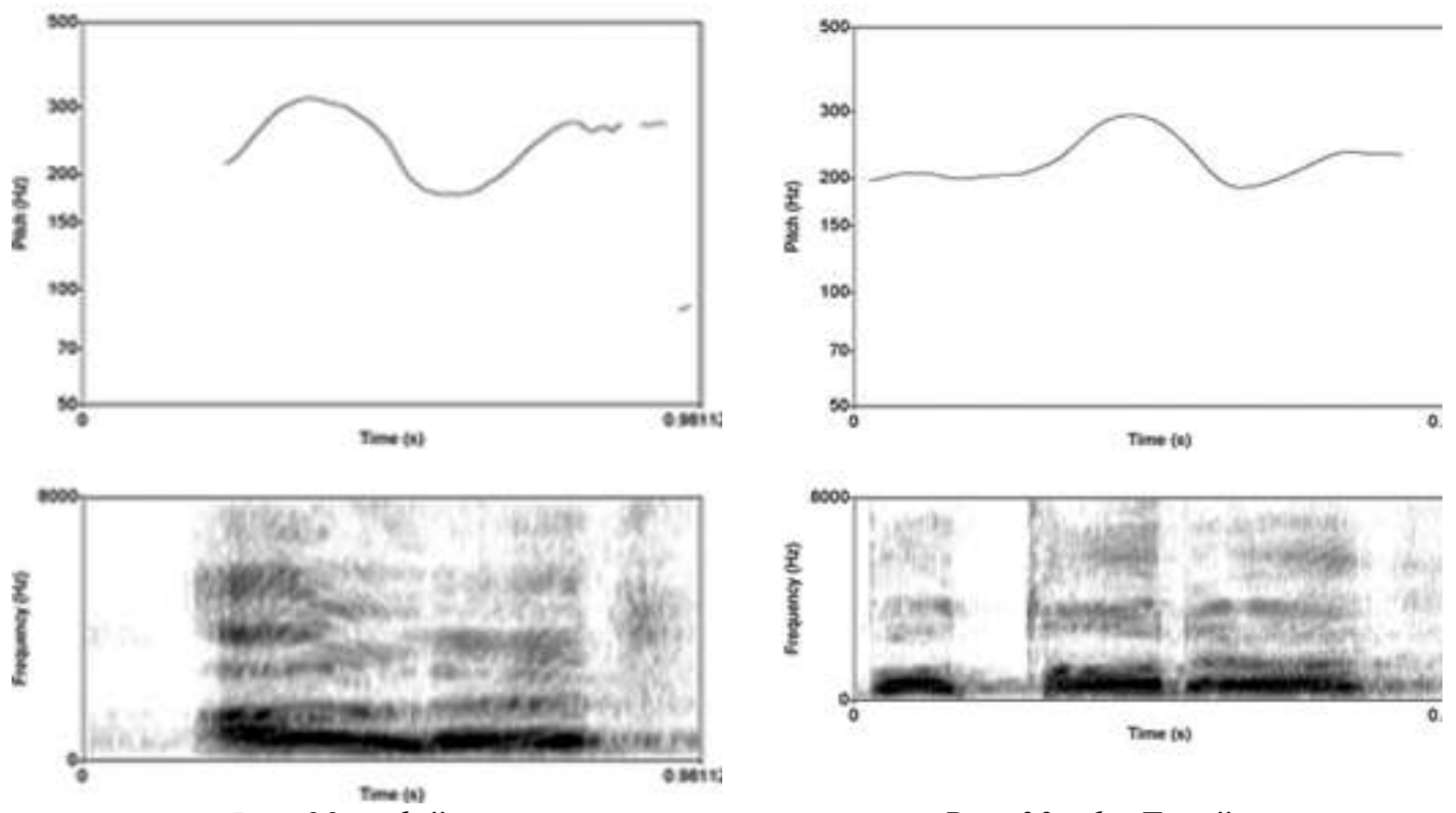

Ryc. 29. „ale”

Ryc. 30. „, bo Tora”

Żydłaczenia" wykorzystane w Akropolis dostrzec także można w wypowiedzi innego aktora, grającego postać Izaaka. Dwukrotnie, w ramach swojej kwestii, dokonał on przesunięcia akcentu paroksytonicznego na ostatnią sylabę wyrazu. Oto jego tekst:

W tlustości ziemie, a w rosie niebieskiej z wierzchu

będzie błogosławieństwo twoje. Z miecza żyć będziesz,

a będziesz stużyt bratu twemu. Ale przyjdzie czas, kiedy

zrzucisz i rozwiqżesz jarzmo jego z szyje twojej.

Rabin Sacha Pecaric również dopuszcza się tego rodzaju zniekształceń akcentuacyjnych, choć nie jest w tym konsekwentny.

Analiza intonacji wymowy scenicznej w spektaklu Akropolis na poziomie wielozdaniowym pozwala ponownie dostrzec zasadę podwajania wysokości dźwięków, na których opierają się poszczególne wypowiedzi aktorów. Jako przykład może posłużyć rozmowa Aniołów z Panią (z pomnika Skotnickiego) (Akt I sc4). W tekście literackim Aniołowie oprowadzają Panią po kaplicy Jagiellonów w Katedrze Wawelskiej. 

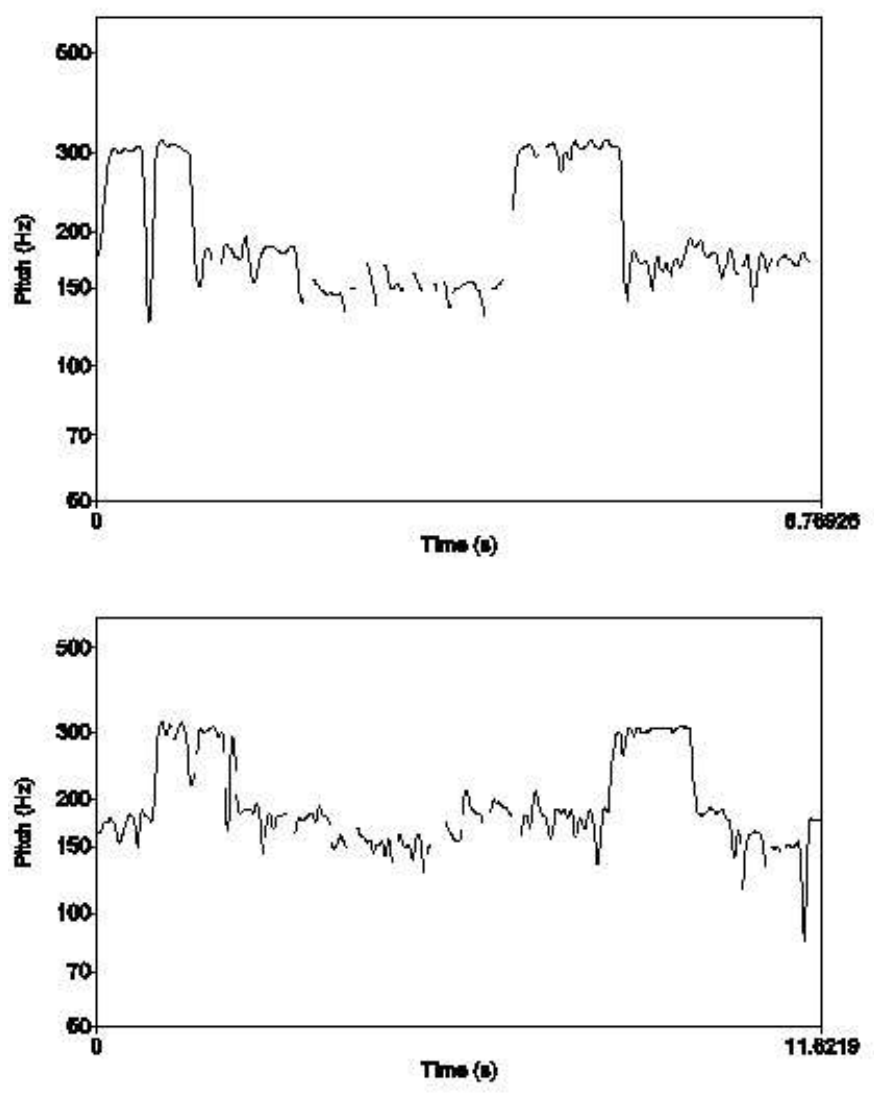

Ryc. 31 (górna) i 32 (dolna).

Aktor grający Anioła 4 mówi na poziomie $300 \mathrm{~Hz}(d 4)$ jasnym głosem, podczas gdy pozostali aktorzy, grający Panią i Anioła 3 mówią odpowiednio w zakresie od $150 \mathrm{~Hz}(d 3)$ do $200 \mathrm{~Hz}(\mathrm{~g} 3)$. Niższa częstotliwość ich wypowiedzi decyduje jednocześnie o ciemniejszym zabarwieniu głosów. $\mathrm{Na}$ intonogramach widoczne są społowienia i podwojenia częstotliwości zarówno w obrębie intonacji wysokiej, jak i intonacji niskich. Skorygowanie tych błędów nie jest jednak możliwe w przypadku analizowania tak długich fragmentów. Wyniki analiz instrumentalnych mogłyby się okazać całkowicie niezgodne $\mathrm{z}$ wrażeniem słuchowym. Powyższy wykres ma charakter ogólno-poglądowy. Oto tekst Anioła 4 na pierwszym wykresie - ryc. 31:

$$
\text { Rozpleć dłonie. (segment I-300 Hz) Bytaś kiedy wesoła? (segment II - } 300 \mathrm{~Hz} \text { ) }
$$

Oto teksty wypowiedzi Pani i Anioła 3, których częstotliwość podstawowa mieści się w zakresie 150 i $200 \mathrm{~Hz}$, po segmentach I i II $(300 \mathrm{~Hz})$ stanowiących pełną wypowiedź Anioła 4 (pierwszy wykres).

Pani: A ból, który mam w tonie-?

Anioł 3: Zapomnij - potrzej czoło. Czy jeszcze co pamiętasz?

Tekst Anioła 4 na drugim wykresie - ryc. 32:

Zeszłaś z grobu.(segment I-300 Hz) Budzę, zapomnij mąk.(segment II - $300 \mathrm{~Hz}$ )

Oto tekst wypowiedzi Pani i Anioła 3, których częstotliwość podstawowa mieści się w zakresie od 150 do $200 \mathrm{~Hz}$. Tekst Pani przed segmentem 300Hz stanowiącym wypowiedź Anioła 4.:

Pani: Stałam na grobie. 
Tekst po w/w $300 \mathrm{~Hz}$ segmencie:

Pani: Na chwile?? Czyli tylko na chwile jedyna?

Anioł 3: Tak, ta jedna godzina budzisz się-

Pani: Ptynq strumienie krwi do rak. Bytam w męce - ty budzisz -?

Tekst po drugim segmencie (kolejnej wypowiedzi Anioła 4):

Pani: Czyli ty mnie nie tudzisz?

Anioł 3: Nie łudze-żyjesz.

Pani: Żyję!!

\subsection{Ksią̇ę Niezłomny wg thumaczenia Juliusza Słowackiego}

Koncepcję zestawiania ze sobą wypowiedzi w relacji podwojenia częstotliowści dostrzec można także w realizacji Księcia Niezłomnego. Poniższe intonogramy i sonogramy prezentują analizę fragmentu rozmowy między Feniksaną - córką Króla Fezu i zakochanym w niej bez wzajemności Mulejem - wodzem galer fezjańskich. Feniksana trzyma, przyniesiony przed chwila przez ojca, portret infanta Tarudanta, który stara się o jej rękę. Mulej, widząc ów portret w jej rękach, czyni jej scenę zazdrości. Feniksana próbuje wyjaśnić Mulejowi, że portret przyniósł jej ojciec, który chce wydać ją za mąż za Tarudanta. Mulej zarzuca jej kłamstwo i żąda innej wymówki. Feniksana twierdzi, że została przymuszona przez ojca do przyjęcia portretu. Kolejność rycin odzwierciedla realny przebieg rozmowy w sytuacji spektaklu. Zwróćmy uwage na charakterystyczny zabieg intonacyjny (podniesienie głosu) wykorzystany przez aktorkę widoczny na rycinie 33, gdzie zaakcentowaniu uległ ostatni wyraz wielki. Obserwujemy tutaj również znaczny spadek częstotliowści z $690 \mathrm{~Hz}$ (okolice f5) do ok. $250 \mathrm{~Hz}$ (h3) na sylabie ki. Aktorka kontunuuje swoją wypowiedź, wykorzystując jednostajną intonację, podobnie jak towarzyszący jej aktor. Ona mówi na średniej wysokości ok. $500 \mathrm{~Hz}$, on - na wysokości ok. 200/230 Hz.
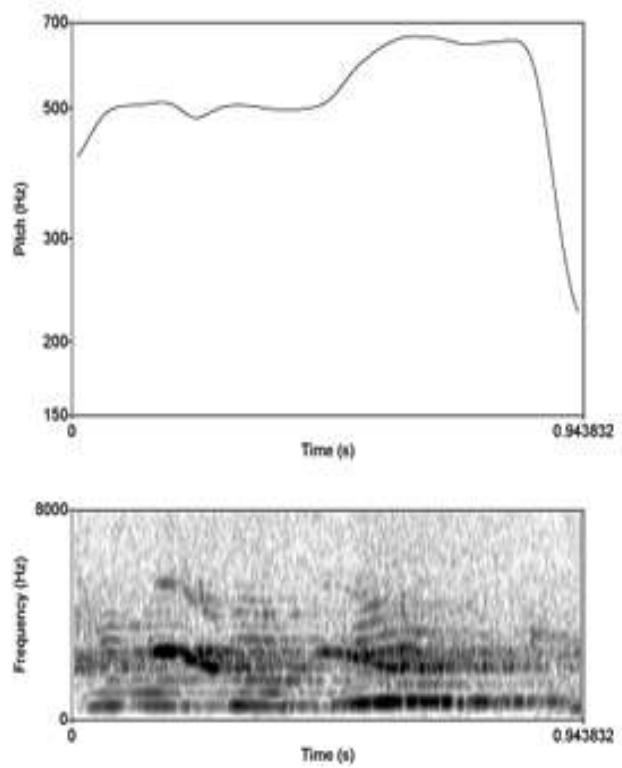

Ryc. 33. Feniksana:" przymus byt wielki"
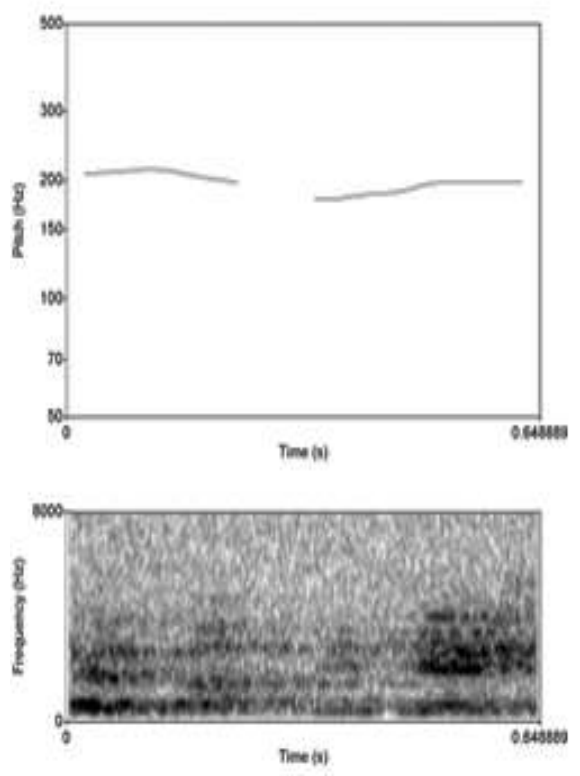

Ryc. 34. Mulej: , serca zmienienie” 

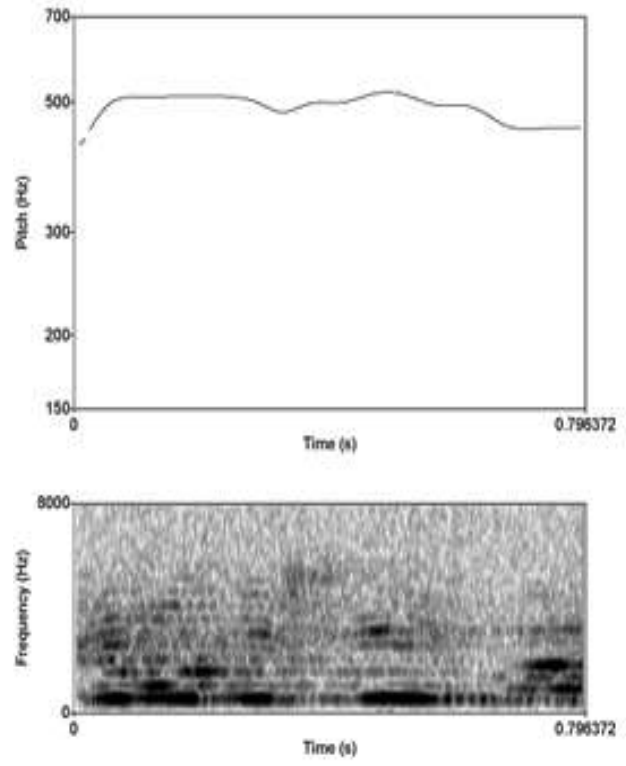

Ryc. 35. Feniksana: ,przymus i siła”
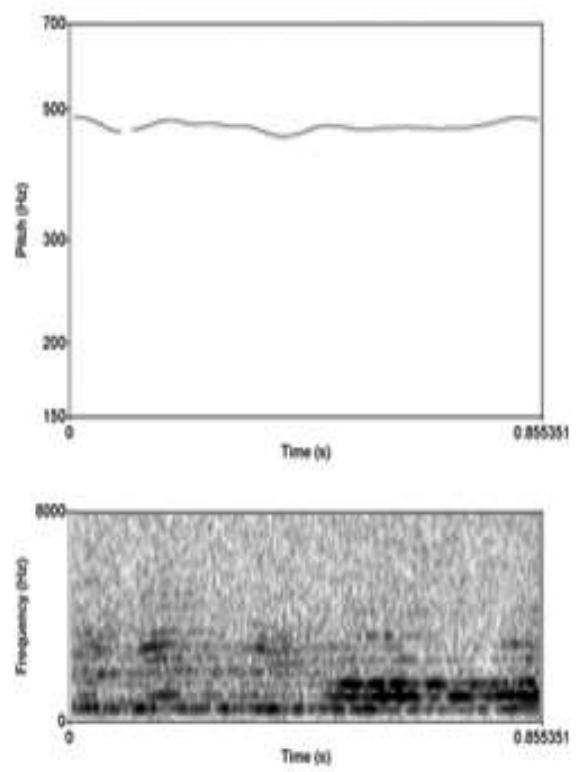

Ryc. 37. Feniksana: „,cóż więc być mogło?"
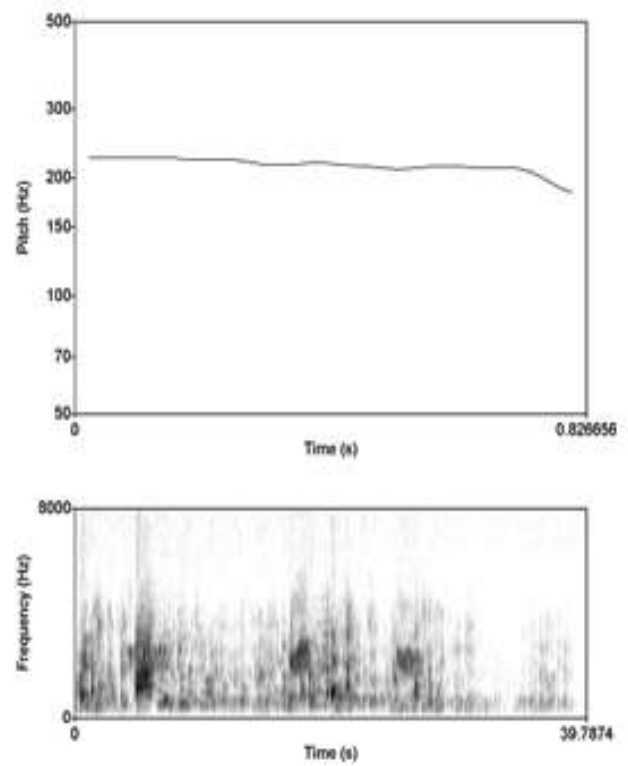

Ryc. 36. Mulej: „,któż się podda sile?”
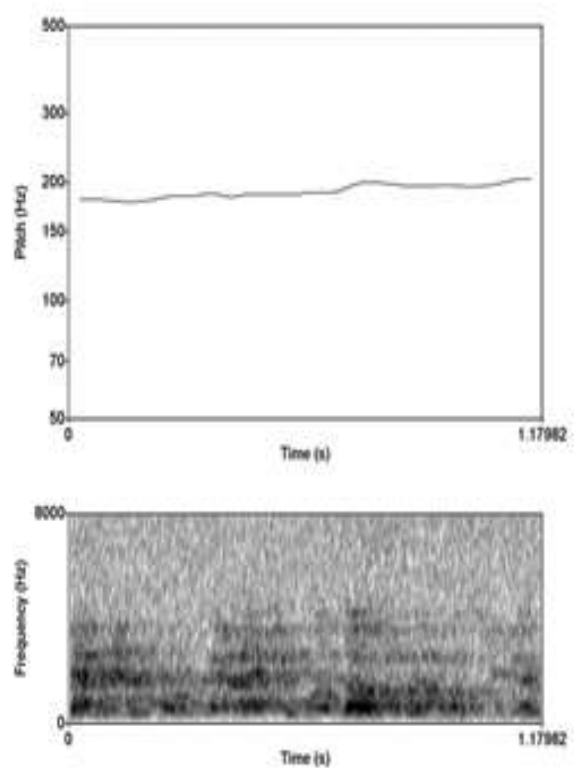

Ryc. 38. Mulej: ,, Oddalenie, oddalenie podobne mogile"

\subsection{Apocalypsis cum figuris}

Intonacja wymowy scenicznej, w ostatnim wyreżyserowanym przez Grotowskiego spektaklu, Apocalypsis cum figuris, nie wykazuje już cech, o których mowa była powyżej. Obserwuje się w tym przypadku większą polaryzację między intonacją wypowiedzi, zbliżoną do intonacji mowy potocznej, a śpiewem. Główny akcent przesunięty został tym razem na wykorzystanie środków paralingwistycznych, takich jak śmiech, głośny oddech, mlaskanie, oraz dodatkowych efektów akustycznych, związanych $\mathrm{z}$ działaniem aktorów na scenie, np. bieganiem lub rytmicznym chodzeniem. Wyjątek stanowią dwa przypadki zastosowania przez aktora spotykanej już we 
wcześniejszych spektaklach strategii intonacyjnej, w której ostatnia sylaba wyrazu podlega zaakcentowaniu rytmicznemu i melodycznemu. Ryciny 39 i 40 prezentują fragmenty wypowiedzi postaci o imieniu Judasz. Postać ta jest grana przez tego samego aktora, który wcielał się w postać Jakuba w przedstawieniu Akropolis. Judasz w spektaklu Apocalypsis cum figuris opowiada Szymonowi Piotrowi fragment przypowieści:

Czlowiek niektóry sprawit wieczerze wielka i zaprosit wielu. I posłat shuge swego w godzinę wieczerzy, żeby rzekł zaproszonym: Pójdźcie, bo już wszystko gotowe. I poczęli się wszyscy spotecznie wymawiać. Piewrszy mu rzekt: Kupiłem wieś i musze iść ogladnać ja, proszę cię, miej mnie za wymówionego. A drugi rzekt: Żonem pojąt, a dlatego przyjść nie mogę. A wróciwszy się oznajmil to panu swemu. Tedy się gospodarz rozgniewawszy rzekt studze swemu: Wynijdź prędko na ulicę i na drogi miejskie, a ułomne i ślepe i chrome wprowadź.
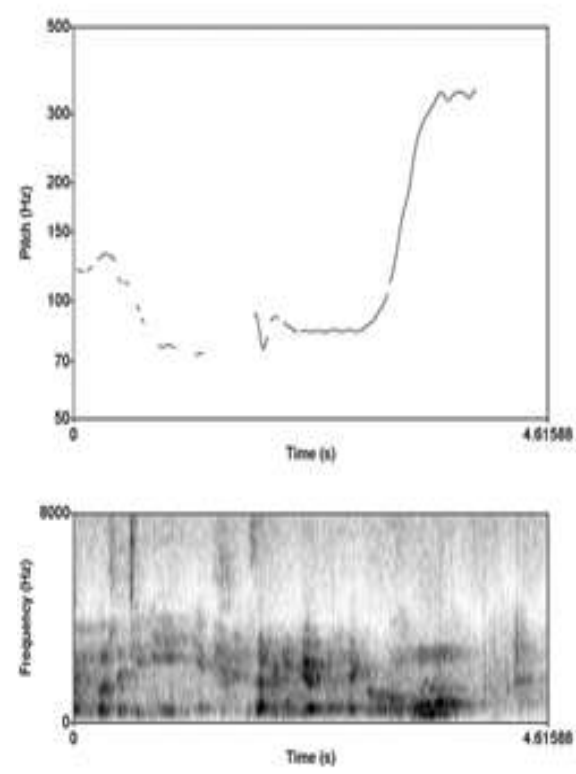

Ryc. 39. „proszę cię, miej mnie za wymówionego"
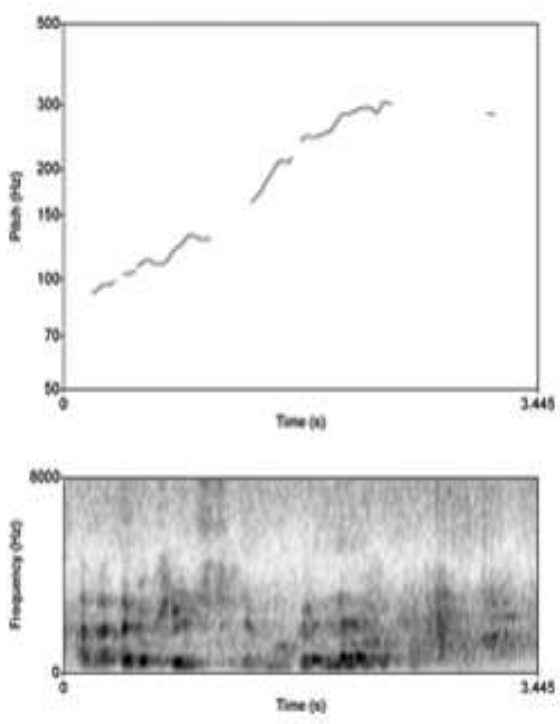

Ryc. 40. „,dlatego przyjść nie moge”

Na rycinie 39 widać, że ostatnia sylaba wyrazu wymówionego została zaakcentowana poprzez wzdłużenie i podniesienie wysokości $85 \mathrm{~Hz}(f 2)$ do $380 \mathrm{~Hz}(g 4)$, a więc ponad dwie oktawy. Na rycinie $40 \mathrm{z}$ kolei widoczny jest stopniowy wzrost częstotliwości na dłuższym odcinku tekstu (nie tylko na samym wyrazie jak na poprzednim przykładzie). Wzdłużenie ostatniej sylaby wyrazu mogę zostało dodatkowo wzmocnione podniesieniem głosu z wysokości ok $140 \mathrm{~Hz}$ (okolice d3) do $300 \mathrm{~Hz}$ (okolice d4), a więc o oktawę. Średnia wartość częstotliwości podstawowej dla całej wypowiedzi wynosi około $100 \mathrm{~Hz}$. Zastosowane przez niego zabiegi intonacyjne pełnią rolę figur retorycznych, podkreślających odmowne odpowiedzi przytoczone w przypowieści.

\section{Wnioski}

Intonacja wymowy scenicznej realizowana przez aktorów laboratorium teatralnego działającego najpierw w Opolu, potem we Wrocławiu, stanowiła zjawisko różnorodne. W jego obrębie można jednak zauważyć pewne powtarzające się schematy w sposobie transformowania słowa literackiego, wykorzystywane w każdym niemal spektaklu. Obserwujemy dążenie aktorów do zachowania paroksytoniczności akcentu, wydłużenia sylab akcentowanych wraz z podwyższaniem i obniżaniem częstotliwości podstawowej lub utrzymywania jej na równym poziomie.

Umuzycznienie wygłoszenia słowa przejawia się na planie intonacyjnym, gdzie określone zabiegi akcentacyjne pełnią rolę retoryczną i jednocześnie instrumentacyjna, polegającą na wyeksponowaniu cech fonicznych tekstu. Intonacja stanowi wreszcie narzędzie pozwalające 
odpowiednio różnicować postaci dramatów, a obserwowane społowienia bądź zdwojenia częstotliwości jednej wypowiedzi względem drugiej dodatkowo świadczą o muzycznej projekcji przedstawienia.

Na kilka słów komentarza zasługuje też zakres dźwięków, jakimi operują aktorzy. W mowie potocznej częstotliwość drgań zmienia się w przypadku kobiet w zakresie od 180 do $400 \mathrm{~Hz}$, w przypadku mężczyzn - w zakresie od 60 do $200 \mathrm{~Hz}$ (Demenko 1999: 20). Analiza spektakli pokazuje, że intonacja grających w nich aktorów dalece odbiega od praktyki spotykanej w innych teatrach repertuarowych. W obrębie ich wypowiedzi obserwuje się skoki częstotliowści dźwięku przewyższające dwie oktawy (ponad $200 \%$ w stosunku do czestotliwości wyjściowej).

Trzeba też zwrócić uwagę na predylekcję Grotowskiego do wykorzystywania inkantacji i stylizacji mowy litanijnej (słyszalnej np. w nabożeństwach Kościoła Katolickiego) na przestrzeni całej działalności teatralnej zespołu. Pełniło to oczywiście niezwykle sugestywną funkcję metaforyczną, dzięki której możliwe było dokonywanie pewnej konfrontacji (zderzenia) odczuć religijnych widza (należących do najbardziej intymnych) z przesłaniem określonego tekstu i tym samym wzbudzenie w nim indywidualnej refleksji.

W kontekście wymowy scenicznej znaczące też wydaje się zagadnienie jej tempa. W tym przypadku dostrzegamy także wielką różnorodność w każdym spektaklu, począwszy od mowy wolnej (stylizowanej na modlitewną) do szybkiej - silnie afektywnej. Ksiażę Niezłomny stanowi swoisty wyjątek pośród innych spektakli, ponieważ momentami aktorzy mówią $\mathrm{w}$ niezwykle szybkim tempie, czasami nawet zaburzającym percepcję semantyki tekstu. W świetle badań językoznawczych tempo wymowy potocznej waha się od waha się od czterech do siedmiu sylab na sekundę (Demenko 1999:29). Górna granica należy do komentarzy sportowych. We wspomnianym spektaklu aktorzy mówią w tempie do 11 sylab na sekundę, w sytuacjach szczególnego napięcia emocjonalnego. Tempo takie zachowuje główny bohater - Książę Niezłomny - w większości swoich monologów. 


\section{Bibliografia}

Ball, M. J., Rahilly, J. 1999. Phonetics. The science of speech. London: Arnold; New York: Oxford Univwersity Press.

Ball M. J., Rahilly J., 1999. Phonetics. The science of speech. London: Arnold; New York: Oxford Univwersity Press. Chodkowski A. (Ed.), 1995. Intonacja. w: Encyklopedia Muzyki, Warszawa: PWN. pp. 392-393.

Demenko G., 1999. Analiza cech suprasegmentalnych języka polskiego na potrzeby technologii mowy. Poznań: Wydawnictwo Naukowe UAM

Degler J., Ziółkowski G., 2006. Misterium zgrozy i urzeczenia, Wrocław: Instytut im. Jerzego Grotowskiego.

Eberhardt K., 1960. Rzecz o niemocy teatru. Ekran 10, pp. 7.

Flaszen L., 1983. Teatr skazany na magię. Kraków-Wrocław: Wydawnictwo Literackie.

Grotowski J., 1972. Co było. Dialog 10, pp. 114.

Grotowski J., 1989. Ku teatrowi ubogiemu. w: J. Degler (Ed.) Teksty z lat 1965-69. Wrocław: Wydawnictwo Naukowe UW. pp. 7-21.

Grotowski J., 1989a. Teatr Laboratorium 13 Rzędów. Jerzy Grotowski o sztuce aktora. w: J. Degler (Ed.) Teksty z lat 1965-69. Wrocław: Wydawnictwo Naukowe UW. pp. 33-39.

Grotowski J., 1989b.Głos. w: J. Degler (Ed.) Teksty z lat 1965-69. Wrocław: Wydawnictwo Naukowe UW. pp. 111-144.

Grotowski J., 1989c. Odpowiedź Stanisławskiemu. w: J. Degler (Ed.) Teksty z lat 1965- 69. Wrocław: Wydawnictwo Naukowe UW. pp. 145-164.

Nooteboom S., 1997. The Prosody of Speech: Melody and Rhythm. w: W. Hardcastle , J., Lawer [Ed.] The Handbook of Phonetic Sciences. Oxford; Cambridge, Mass: Blackwell Publ. pp. 640-673.

Jędrzejczyk O., Opolska „Siakuntala”, Gazeta Krakowska 1960, nr 307, pp. 8.

Karpiński M., 2006. Struktura i intonacja polskiego dialogu zadaniowego. Poznań: Wydawnictwo Naukowe UAM.

Kudliński T., 1961. Siakuntala biomechaniczna. Dziennik Polski 15, pp. 4.

Lau J., 1961. Poszukiwacze teatru środka. Argumenty 4, pp. 6.

Leja M., 1961. Cudzoziemka w Opolu. Sztandar Młodych 5, pp. 2.

Majchrowski Z., 1998. Cela Konrada. Powracajac do Mickiewicza. Gdańsk: Słowo/obraz/terytoria.

Nowakowski P., 1997. Wariantywność współczesnej polskiej wymowy scenicznej, Poznań: Sorus.

Oddham G., 2001. Intonation, w: New Grove Dictionary of Music and Musicians vol. 12, Oxford, pp. 503.

Osiński Z., 1967. Przekład tekstu literackiego na język teatru, w: J. Trzynadlowski (Ed). Dramat i teatr. Konferencja teoretyczno-literacka w Świętej Katarzynie. Wrocław, pp. 119-150.

Osiński Z., Burzyński T., 1978. Grotowski’s Laboratory. Warszawa: Interpress.

Osiński Z., 2000. Zapiski ze spotkań 1962-63, Notatnik Teatralny 20-21, pp. 110-125.

Pawłowski Z. 2002. Foniatryczna diagnostyka wykonawstwa śpiewu i gry na instrumentach dętych. Warszawa: Wydawnictwo AM.

Pawłowski Z., 2005. Foniatryczna diagnostyka wykonawstwa emisji głosu śpiewaczego i mówionego. Kraków: Oficyna Wydawnicza Impuls.

Stanisławski K., 1954. Praca aktora nad sobą cz. II. w: Pisma.T. 4, Warszawa 1954.

Steffen-Batogowa M., 1996. Struktura przebiegu melodii polskiego języka ogólnego. Poznań: Sorus.

t'Hart J., Collier R., Cohen A., 1990. A perceptual study of intonation. An Experimental-phonetic approach to speech melody. Cambridge University Press.

Wójtowicz A., 2004. Od Orfeusza do Studium o Hamlecie Teatr 13 Rzędów w Opolu 1959-1964. Wrocław: Wydawnictwo Naukowe UW. 